\title{
ESTRATEGIA DE LOS PARTIDOS \\ Y ESCISIONES DE MASAS EN LAS ELECCIONES PARLAMENTARIAS ESPAÑOLAS DE 1979 *
}

\author{
POR \\ GIACOMO SANI \\ Professor of politics, Ohio State University \\ RICHARD GUNTHER \\ Assistant professor of politics, Ohio State University \\ $\mathrm{Y}$ \\ GOLDIE SHABAD \\ Assistant professor of politics, Ohio State University
}

\begin{abstract}
Este estudio ha sido financiado por la «National Science Foundation» bajo la beca n. ${ }^{\circ}$ SOC77-16451. Las opiniones, re sultados y conclusiones expresadas en él son responsabilidad de los autores y no reflejan necesariamente los puntos de vista de la «National Science Foundation». Deseamos agradecer la ayuda que nos ha sido prestada por la Ohio State University's Polimetric Laboratory. Nos encontramos particularmente agradecidos a Juan Linz por su estímulo y ayuda.
\end{abstract}

Las estrategias electorales, el comportamiento de las élites de los partidos y la respuesta de los ciudadanos son cruciales en la naturaleza de cualquier sistema de partidos. Ello es particularmente cierto en los primeros estadios del desarrollo de una democracia política. Aquellas escisiones dentro de una sociedad que los políticos deciden enfatizar y aquellas otras que tienen mayor resonancia a nivel de masas en esta primera fase van probablemente a estructurar el conflicto político de una forma permanente $y$, por ello, a condicionar el desarrollo del sistema de partidos en el futuro. Las divisiones sociales y económicas objetivamente definibles ayudan ciertamente a determinar cuáles de ellas juegan roles políticos significativos, pero no son, sin embargo, por sí solas suficientes. Las determinantes más importantes de la estructura del conflicto partidista son aquellos aspectos de tales conflictos que resultan más des-

* Este trabajo fue presentado en 1980 en el encuentro anual de la American Political Science Association en Washington, D. C. Richard Gunther es autor de Public Policy in a No-Party State y de varios artículos sobre política española contemporánea. Giacomo Sani ha enseñado en el pasado en las Universidades de Bolonia y Florencia; diversos artículos suyos se han publicado en revistas americanas y europeas. Goldie Shabad es autora de varios artículos sobre comportamiento político de masas en Europa y los Estados Unidos.

Este artículo fue publicado originalmente en World Affaires, vol. 143, núm. 2, otoño 1980, págs. 163-216.

Traducción española: Pilar del Castillo Vera

Revista de Derecho Politico

Núm. 11. Otoño 1981 
tacados a nivel de masas y las estrategias ideológicas y organizativas utilizadas por las élites políticas para movilizar el apoyo popular.

El resurgimiento en los últimos años de una democracia política en España nos ofrece una oportunidad para examinar detenidamente la interacción entre élites y masas en la formación de un sistema competitivo de partidos. En este trabajo se consideran tres cuestiones: 1) hasta qué punto los tres conflictos históricamente más importantes (diferencias de clase, religión y región) han reemergido en el nuevo sistema de partidos; 2) por encima y más allá de estos conflictos, cuáles son las divisiones estrictamente políticas más significativas que caracterizan la nueva política española, y 3) cuáles son las consecuencias de la estructura del conflicto en su conjunto para la competición entre los partidos.

Analizaremos estos problemas centrándonos en las elecciones parlamentarias de 1979. Si bien es cierto que ellas no constituyen el primer contexto partidista de la era posfranquista, pueden ser consideradas como las primeras elecciones «normales»: tuvieron lugar al final del período de transición, una vez aprobada la nueva Constitución; se celebraron después de una simplificación de las alternativas electorales, en la cual el número de partidos relevantes se redujo de más allá de cien a alrededor de media docena; y, por último, los partidos más importantes llevaban para entonces cerca de dos años legalizados, lo que significaba que habían tenido una oportunidad para implantarse. De esta forma, la campaña de 1979 ofrece quizá una mejor oportunidad que el más apasionante pero confuso contexto de 1977 para observar a los políticos $\mathrm{y}$ votantes en acción.

Los datos que se ofrecen en este trabajo están extraídos de una encuesta a nivel nacional sobre el electorado español llevada a cabo en la primavera de $1979^{1}$, de un conjunto de entrevistas pre y poselectorales con líderes de los partidos a nivel nacional y provincial ${ }^{2}$, del material sobre las elecciones distribuido por los partidos y de la información de la campaña a través de los medios de comunicación ${ }^{3}$.

${ }^{1}$ Una muestra estratificada de probabilidad de 5.439 votantes españoles, de dieciocho años en adelante de edad. Fueron encuestados entre mediados de abril y mediados de junio de 1979. Las encuestas feuron llevadas a cabo por encuestadores cualificados de DATA, Sociedad Anónima, de Madrid. En orden a facilitar el análisis de las poblaciones regionales, muestras extras fueron diseñadas para Cataluña, Galicia, Navarra, Valencia y Euskadi.

Deseamos dar las gracias a Manuel Gómez-Reino, Francisco Andrés Orizo, Darío Vila Cano, Antonio Pons Puig, Maite González Royo, Nuria de Loresecha Sánchez, Guillermo Pacheco del Olmo y Nicolás García Muñoz, de DATA, S. A., por su ayuda durante las distintas fases de este proyecto.

${ }_{2}$ Las entrevistas no estaban limitadas de antemano y fueron llevadas a cabo por Richard Gunther al final de la primavera y durante el verano de 1978 y en el verano de 1979 en las siguientes provincias: Madrid, Toledo, Segovia, Zamora, Navarra, Guipúzcoa, Barcelona, Gerona, Valencia, Pontevedra, La Coruña, Sevilla, Córdoba, Málaga, Granada y las Islas Baleares. Se llevaron a cabo setenta entrevistas antes de las elecciones y aproximadamente un número igual después de ellas.

${ }^{3}$ Los materiales recopilados incluyen: programas de los partidos, folletos, posters, textos de las intervenciones de los líderes políticos y de otros participantes significativos, grabaciones de las emisiones de radio y televisión y ejemplares de los diarios más importantes publicados durante la campaña. Además de ello, Giacomo Sani y Goldie Shabad siguieron numerosos mítines de la campaña en Madrid. 


\section{R E L I G I O N}

La relación entre política y religión en España ha sido a la vez larga y tumultuosa: Durante años ha generado un intenso conflicto político y numerosos estallidos de violencia anticlerical, especialmente en el primer tercio del siglo $\mathrm{xx}^{4}$. Tales tensiones se encontraban claramente reflejadas en el sistema de partidos de la II República, en la cual los partidos de la burguesía anticlerical (como la Izquierda Republicana de Azaña) y los partidos de la izquierda (como el Partido Socialista Obrero Español _PSOE-) estaban radicalmente enfrentados a la derechista CEDA y a otras fuerzas clericales ${ }^{5}$. Al final esta clase de conflictos basados en la religión no pudieron ser satisfactoriamente regulados y contribuyeron de forma decisiva al estallido de la guerra civil española ${ }^{6}$. Con el resurgimiento de la democracia a mitad de los años setenta, los observadores podrían legítimamente preguntarse si este conflicto patente y profundamente arraigado supondría una amenaza a la estabilidad tan seria como lo fuera en el pasado. La política competitiva bajo el nuevo régimen democrático tuvo un buen comienzo a este respecto. La jerarquía de la Iglesia declaró su neutralidad en las elecciones a las Cortes Constituyentes de 1977, y dicha imparcialidad fue estrictamente mantenida en toda España, como muchos de nuestros entrevistados declararon. La ausencia de intervención de la Iglesia en aquella campaña, ha argumentado Juan Linz ${ }^{7}$, contribuye poderosamente a explicar por qué los partidos demócrata-cristianos (los cuales algunos estudios habían indicado que podrían recibir un gran apoyo electoral en la era posfranquista) fueron destruidos en las elecciones de $1977^{\circ}$. De esta manera, el sistema de partidos que surgió a raíz de las primeras elecciones no contaba con partidos estrictamente confesionales.

Esto no significa, sin embargo, que la religión no jugara ningún rol en la política española. En el período comprendido entre las dos elecciones generales, Unión de Centro Democrático (UCD), la cual absorbió con éxito muchos de los

- Para una información más amplia sobre esta relación véase Vicens Vives, Approacbes to the History of Spain (Berkeley: University of California Press, 1967). Para un estudio más detallado de las relaciones Iglesia-Estado y conflictos clericales-anticlericales, véase Gerald Brenan, The Spanish Labryntb (Cambridge: Cambridge University Press, 1976); Stanley Payne, The Spanish Revolution (New York: W. W. Norton, 1970), y Raymond Cazz, Spain: 1808-1939 (Oxford: Clarendon Press, 1966).

${ }^{5}$ Para un mejor conocimiento de la actividad de los partidos en la II República véase Juan J. Linz, «The Party System in Spain: Past and Future», en Party Systems and Voter Alignments, Ed. Seymour Martin Lipset and Stein Rokkan (New York: Free Press, 1967).

- Un análisis de como contribuyeron las tensiones Iglesia-Estado al estallido de la guerra civil española se encuentra en Richard Gunther y Roger A. Blough, "Conflicto y consenso religioso en España: historia de dos Constituciones», en Revista de Estudios Políticos, núm. 16, primavera 1980.

${ }_{7}$ Juan Linz, "The New Spanish Party System», en Electoral Participation, Ed. Richard Rose (London: Sage, de próxima aparición).

- Linz, «The Party System in Spain»; y (para datos recopiados en 1976 que mantienen el mismo punto de vista, véase Darío Vila Carro, Francisco Andrés Orúzo y Manuel Gómez-Reino, «Sociología dèl actual cambio político en España», en FOESSA, III informe, Madrid, 1978, pág. 708. 
destrozados restos de la élite de la Democracia Cristiana y Alianza Popular (AP) ${ }^{9}$, mostró sus simpatías hacia la Iglesia, mientras que el Partido Comunista de España (PCE), y especialmente el PSOE, adoptaron una posición anticlerical en muchos aspectos. Tal conexión entre religión y política no alcanzó a forjar lazos organizativos entre los partidos y la Iglesia. Como un líder de Alianza Popular explicaba (en una declaración que podría ser igualmente válida para UCD), «nuestro partido no es confesional a pesar de que defienda las grandes tradiciones cristianas de España». Tanto AP como UCD evitaron establecer asociaciones formales a nivel local y provincial incluso con instituciones cuasi religiosas, tales como las organizaciones de padres de alumnos, y muchos de los entrevistados de UCD en particular declararon durante las entrevistas que los partidos deberían evitar cuidadosamente semejantes vínculos formales en orden a prevenir la repetición de los trágicos sucesos de los años treinta.

La injerencia más directa de la religión dentro de la política tuvo lugar, en cambio, en el curso de las negociaciones interpartidos sobre la Constitución española ${ }^{10}$. Dada la estrecha relación Iglesia-Estado en el régimen franquista (bajo el cual el catolicismo era la religión oficial del Estado, la Iglesia monopolizaba los mattimonios y los entierros y controlaba el sistema educativo), era claro que una significativa alteración de las relaciones habría de tener lugar. El PSOE inicialmente favoreció posiciones maximalistas y anticlericales en las cuestiones más relevantes: propició una separación abrupta y total de la Iglesia y el Estado, la legalización en el propio texto constitucional del divorcio y el aborto, la supresión de los subsidios estatales a los colegios religiosos y, finalmente (como se describe en el programa de educación adoptado en el XXVII Congreso del partido), «la progresiva desaparición de la enseñanza privada» ${ }^{11}$. AP y UCD, de otro lado, defendieron una ampliación de la libertad religiosa, pero exigían que la Iglesia mantuviera un status privilegiado en la nueva Constitución ${ }^{12}$, se opusieron firmemente a la legalización del aborto y a una ley de divorcio liberal y, más importante, defendieron el mantenimiento de los subsidios estatales a los colegios religiosos y la protección de éstos de una excesiva regulación estatal. El PCE, bastante interesadamente, mantuvo una posición casi neutral en todo el proceso de debate. Votó a favor de mantener los subsidios estatales a los centros religiosos y de una mención especial de la Iglesia católica en el texto constitucional, si bien defendió también la legalización del divorcio y del aborto. «Hemos asistido a estos debates en gran

- La primera serie de nuestras entrevistas fueron mantenidas con miembros de AP antes de la constitución de Coalición Democrática. Ello explica que en el texto nos refiramos a este grupo político unas veces como AP y otras como CD.

${ }^{10}$ Un análisis de estas negociaciones constitucionales se puede encontrar en Gunther y Blough, «Conflicto y consenso religioso en España».

${ }^{11}$ Véase PSOE, XXVII Congreso, Programa de transición: La enseñanza, pág. 8.

${ }_{12}$ Específicamente, los representantes de AP y UCD en la Ponencia de la Comisión de Asuntos Constitucionales y Libertades Públicas del Congreso de los Diputados añadieron al artículo 16 de la Constitución (el cual introducía la separación Iglesia-Estado), la siguiente declaración: «Los poderes públicos tendrán en cuenta las creencias religiosas de la sociedad española y mantendrán las consecuentes relaciones con la Iglesia católica y otras confesiones.» 
parte como espectadores», señalaba un diputado del PCE ante el Congreso de los Diputados ${ }^{13}$. La posición armonizadora sostenida por los representantes del PCE durante aquellos debates parece haber estado motivada por un deseo de evitar enfrentamientos que pudieran haber polarizado a la sociedad española y finalmente hubieran repercutido negativamente en los partidos de izquier$\mathrm{da}{ }^{14}$. Una solución de compromiso sobre estos aspectos de la Constitución apaciguó temporalmente aquellas tensiones. Por el contrario, en las elecciones generales de 1979 volvieron a renacer las tensiones. Al comienzo de la campaña, la Conferencia Episcopal publicó un documento ( $« \mathrm{La}$ responsabilidad moral del voto») llamando a los católicos a oponerse a aquellos partidos «en cuyos programas existen compromisos ideológicos o prácticos que afecten a los valores religiosos o derechos fundamentales...», y especialmente les instaba a votar contra «las ideologías materialistas de uno u otro signo, los modelos totalitarios de sociedad o el uso de la violencia como método de lucha política». Por lo que se refiere a esta elección, el documento continuaba: «Nos encontramos particularmente preocupados con aquellas propuestas a favor de la legalización del aborto, la ley del divorcio y la legislación en materia de educación que limite el derecho de los padres a escoger la clase de educación que debería ser dada a sus hijos» ${ }^{15}$. La Conferencia Episcopal había abandonado su previa imparcialidad - se argumentaba en la declaración- porque la Iglesia «no puede ser indiferente al destino de nuestro pueblo» y no podía "permanecer neutral cuando se enfrenta a una posible amenaza contra los valores éticos y los derechos humanos» ${ }^{16}$. Aunque los partidos no fueron específicamente mencionados, la declaración fue claramente interpretada como dirigida contra comunistas y socialistas y en beneficio de los partidos centristas y conservadores. UCD y Coalición Democrática (CD) intentaron capitalizar la declaración de los obispos recordando al electorado la amenaza que la posición de los partidos de la izquierda suponía para la institución de la familia y la educación religiosa, a la vez que las bases «cristiano humanistas» de sus propias ideologías ${ }^{17}$. El más significativo de estos llamamientos fue el llevado a cabo por el primer ministro Adolfo Suárez durante la última emisión televisiva de la campaña. Planteó una elección entre «la perspectiva del humanismo cristiano en la que se inspira UCD (y)... el materialismo de los marxistas, de los partidos socialista o comunista» ${ }^{18}$. Especialmente severa fue su crítica hacia el PSOE, cuyo «programa

${ }^{13}$ Diario de Sesiones del Congreso de los Diputados, núm. 106, 7 de julio de 1978, página 3993.

${ }_{14}$ Véase la intervención de Santiago Carrillo ante el Congreso de los Diputados explicando la posición del PCE sobre los artículos religiosos de la Constitución, Diario de Sesiones, núm. 106, pág. 3994.

${ }_{15}$ Texto según aparece reproducido en Informaciones, Madrid, 9 de febrero de 1979, página 31 .

16 Ibid.

17 Véase, por ejemplo, declaraciones como las de Adolfo Suârez (Informaciones, 10 de febrero de 1979, pág. 4); Miguel Herrero de Miñón (Informaciones, 15 de febrero de 1979, página 4); Manuel Fraga Iribarne (Informaciones, 19 de febrero de 1979, pág. 4); Ramón Alvarez de Miranda (Informaciones, 20 de febrero de 1979, pág. 5); José María de Areilza (Informaciones, 23 de febrero de 1979, pág. 6), y varios anuncios de propaganda aparecidos en Informaciones y otros diarios a lo largo de toda la campaña.

${ }_{18}$ Informaciones, 28 de febrero de 1979, pág. 3. 
del 27th Congreso defiende el aborto libre y la desaparición de la educación religiosa» ${ }^{19}$.

Los partidos de la izquierda respondieron inmediatamente al documento de la Iglesia, adoptando, sin embargo, una considerable moderación al hacerlo. En sus declaraciones criticaron las injerencias de los obispos en los asuntos políticos, pero evitando cuidadosamente atacar a la Iglesia en sí misma ${ }^{20}$. A partir de esta respuesta inicial ningún partido hizo posteriores referencias a la Iglesia a lo largo de la campaña. La racionalización de esta actitud era explicada con las siguientes palabras por un líder comunista:

Indudablemente nosotros no respondimos (a la declaración de los obispos) con ningún tipo de batalla frontal. Pensábamos que ya existían suficientes experiencias históricas de lo que había sido el clericalismo y el anticlericalismo en este país. Hemos criticado a veces aspectos de la Iglesia, los cuales en ciertos momentos parecían estar ligados a los intereses del gran capital, pero nunca hemos entrado dentro de la dinámica de cristianos/ateos. Nunca quisimos entrar en la dinámica de responder permanentemente, sino que, por el contrario, nos hemos ocupado de los problemas diarios de los cristianos, que son los mismos que los de cualquier otro trabajador.

Un factor que contribuyó a esta moderación fue que los partidos de la izquierda creían que ellos tenían muy poco que ganar con la reaparición de esta línea de conflicto. Fueron conscientes de que el clero no era políticamente homogéneo y de que atacar a la Iglesia como un todo podría alinear a los segmentos más progresistas dentro de ella. La percepción de la heterogeneidad de la Iglesia era además compartida —y lamentada- por portavoces de otros partidos. Un diputado de AP, por ejemplo, comentaba:

Lo que es curioso es que en algunos lugares se ejerce influencia en favor de AP, en otros en favor de UCD, en otros a favor del Partido Comunista o del Partido Socialista; de esa manera, la Iglesia reparte su influencia entre varios sectores, dado que realmente depende de la ideología de cada párroco. Sin embargo, la Iglesia jugó un rol fundamental, aunque no uniforme ni institucionalmente influyente, sino que más bien diversas personalidades de la misma ejercieron una gran influencia durante estas elecciones.

Muchos de los políticos entrevistados por nosotros percibían en los más altos niveles de la jerarquía eclesiástica una división entre elementos progresistas y conservadores, y algunos de ellos creían que la publicación del documento episcopal era una medida de compromiso diseñada para prevenir una cruzada anticomunista de mayor virulencia por las fuerzas más tradicionales. Muchos sacerdotes son percibidos por nuestros entrevistados como activistas

19 Ibid.

- Véase el texto de esa declaración en Informaciones, 9 de febrero de 1979, pág. 31. 
de la izquierda. En Andalucía, por ejemplo, el centro de gravedad política del clero parece encontrarse claramente a la izquierda del centro; en Navarra los sacerdotes y los ex sacerdotes están considerados como el principal núcleo de la élite que apoya a la extrema izquierda y a los partidos separatistas vascos ${ }^{21}$.

En opinión de varios entrevistados, esta heterogeneidad ideológica ayudó a atenuar el impacto de la Conferencia Episcopal en lá campaña de 1979. Un miembro del PCE fue más lejos todavía al decir que «esta división dentro de la propia Conferencia Episcopal entre ultras y centristas incapacita a la Iglesia para una intervención electoral». Aunque la declaración hecha pública por los obispos era un modo no deseable de influir sobre la campaña —añadía-, «no podemos pensar de ninguna forma que en España ha habido una beligerancia electoral peligrosa de la Iglesia hacia los partidos de izquierda». Las palabras más duras dirigidas contra la Iglesia en el curso de nuestras entrevistas no vinieron, de hecho, de los partidos de la izquierda, sino, por el contrario, de varios miembros de $\mathrm{AP}$, quienes amargamente se resentían del apoyo explícito a UCD del diario $Y a^{22}$. En suma, la élite política española optó durante el curso de la campaña de 1979 por no enfatizar esta dimensión del conflicto que había demostrado ser tan explosiva en el pasado.

El potencial de polarización por lo que se refiere a los problemas religiosos, los cuales las élites aparentemente contemplaban con aprehènsión, resulta de hecho bastante notorio a nivel de masas. La población se encuentra dividida tanto en el nivel de religiosidad y sentimientos hacia la Iglesia cuanto en el del impacto de ésta en la sociedad española. Importantes sectores de votantes están situados en los dos extremos del continuum religioso («muy buen católico» o «practicante», 42 por 100; «indiferente» o «ateo», 17 por 100). La polarización por lo que respecta a los sentimientos hacia la Iglesia es incluso más nítida (el 26 por 100 mantiene sentimientos negativos, $\mathrm{y}$ el 30 por 100 manifiesta opiniones positivas; el 42 por 100 cree que la Iglesia tiene una influencia beneficiosa, y el 28 por 100 , un efecto perjudicial).

Lo que hace a estas divisiones aún más significativas es el hecho de que se encuentran estrechamente relacionadas con las inclinaciones partidistas. Los simpatizantes de los partidos de izquierda y los de los partidos de centroderecha aparecen claramente separados por la religiosidad. Como el cuadro 1 demuestra, entre los últimos aproximadamente dos tercios pueden ser clasificados como católicos «buenos» o «practicantes»; entre los votantes de la izquierda, el porcentaje correspondiente no excede de 25 puntos, y en el caso del PCE y de la extrema izquierda alcanza tan sólo al 10 por 100. Igualmente reveladores son los porcentajes que corresponden a las categorías de «indiferentes». o «ateos».

2t El PCE trató asimismo de difuminar su imagen anticlerical incluyendo "sacerdotes como candidatos en las elecciones múnicipales de abril de 1979. El actual alcalde de Santa Coloma, uno de los pueblos de mayor número de habitantes de Barcelona, es miembro del PCE y sacerdote.

22 Ello tomó forma de dos editoriales (una publicada el día antes de las eleccionés, 28 de febrero, pág. 5, y otra el mismo día en que éstas se celebraban, 1 de marzo, pág. 5), llamando simultáneamente a una participación electoral activa para derrotar al PSOE y a que el voto no fuera malgastado, es decir, un voto útil para UCD, en lugar de un voto desperdiciado para $C D$. 
Cuadro 1

PORCENTAJE DE RELIGIOSIDAD POR PREFERENCIA PARTIDISTA *

\begin{tabular}{|c|c|c|c|c|c|c|c|c|}
\hline & \multicolumn{8}{|c|}{ PREFERENCIA DE PARTIDO } \\
\hline & $\begin{array}{c}\text { Extrema } \\
\text { Izq. }\end{array}$ & $\begin{array}{l}\text { Izq. } \\
\text { Reg. }\end{array}$ & $\begin{array}{l}\text { Comu- } \\
\text { nistas }\end{array}$ & $\begin{array}{l}\text { Socia- } \\
\text { listas }\end{array}$ & $\begin{array}{l}\text { Reg. } \\
\text { Mod. }\end{array}$ & UCD & CD & $\begin{array}{l}\text { Extrema } \\
\text { Derecha }\end{array}$ \\
\hline 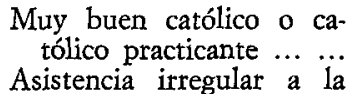 & 9,3 & 20,9 & 11,8 & 24,1 & 51,0 & 61,9 & 63,6 & 63,2 \\
\hline iglesia o no practicante. & 24,3 & 33,9 & 41,6 & 53,2 & 36,3 & 33,8 & 32,5 & 28,4 \\
\hline 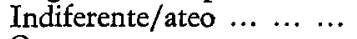 & 65,9 & 42,0 & 45,4 & 21,5 & 10,7 & 3,3 & 3,2 & 6,9 \\
\hline 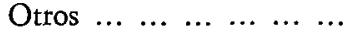 & 0,5 & 3,2 & 7,2 & 7,2 & 2,0 & 7,0 & 0,7 & 1,5 \\
\hline $\begin{array}{lllllllll}N & \ldots & \ldots & \ldots & \ldots & \ldots & \ldots & \ldots\end{array}$ & (73) & $(120)$ & $(400)$ & $(1278)$ & $(156)$ & $(1658)$ & $(173)$ & (56) \\
\hline
\end{tabular}

* E1 agrupamiento por partidos de los encuestados basado en el voto de 1979 y/o 1977 o en la identificación con un partido por algunos votantes es el siguiente:

Extrema Izquierda: ORT, EMK-OIC, LKI-LCR, PTE, PTA, OCE-BR.

Izquierda Regional: EE, HB, BEAN, BNPG, UPC.

Comunistas: PCE, PSUC.

Socialistas: PSOE.

Coalición Democrática: UF, UPN, $\mathrm{CD}$.

Extrema Derecha: UN, FEJ, FN.

Una relación similar se mantiene si atendemos a las opiniones que se refieren a la influencia que en conjunto la Iglesia ejerce en la sociedad española (cuadro 2). Aunque en todos los grupos de simpatizantes de los partidos se incluyen considerables sectores de personas que creen que la Iglesia no tiene hoy influencia, la proporción de aquellos que creen que tiene una influencia beneficiosa y de aquellos que creen que tiene una influencia perjudicial aparece dividida en función de las preferencias partidistas.

\section{CuAdro 2}

PORCENTAJES DE LAS OPINIONES EXPRESADAS POR LOS VOTANTES SOBRE LA INFLUENCIA DE LA IGLESIA EN LA SOCIEDAD ESPAÑOLA POR PREFERENCIA PARTIDISTA

\begin{tabular}{|c|c|c|c|c|c|c|c|c|}
\hline & \multicolumn{8}{|c|}{ PRERERENCIA DE PARTIDO } \\
\hline & $\begin{array}{c}\text { Extrema } \\
\text { Izq. }\end{array}$ & $\begin{array}{l}\text { Izq. } \\
\text { Reg. }\end{array}$ & $\begin{array}{l}\text { Comu- } \\
\text { nistas }\end{array}$ & $\begin{array}{l}\text { Socia- } \\
\text { listas }\end{array}$ & $\begin{array}{l}\text { Reg. } \\
\text { Mod. }\end{array}$ & UCD & CD & $\begin{array}{l}\text { Extrema } \\
\text { Derecha }\end{array}$ \\
\hline $\begin{array}{ccccc}\text { Beneficiosa } & \ldots & \ldots & \ldots & \ldots\end{array}$ & 3,6 & 13,1 & 11,9 & 27,5 & 50,7 & 63,2 & 58,0 & 54,7 \\
\hline Ninguna influencia ... & 19,8 & 17,7 & 20,4 & 33,5 & 23,7 & 23,6 & 24,8 & 24,8 \\
\hline $\begin{array}{lllll}\text { Perjudicial } & \ldots & \ldots & \ldots & \ldots\end{array}$ & 73,6 & 64,5 & 64,6 & 35,3 & 20,8 & 9,5 & 13,3 & 18,8 \\
\hline 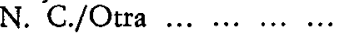 & 3,0 & 4,7 & 3,1 & 3,7 & 4,8 & 3,7 & 3,9 & 1,7 \\
\hline $\begin{array}{lllllllll}N & \ldots & \ldots & \ldots & \ldots & \ldots & \ldots & \ldots\end{array}$ & (73) & $(170)^{\circ}$ & $(400)$ & $(1778)$ & (156) & $(1658)$ & (173) & $(56)$ \\
\hline
\end{tabular}

Como en el caso de otros indicadores, los votantes del PSOE están más acusadamente escindidos en lo que concierne al beneficioso o perjudicial im- 
pacto de la Iglesia que los de otros grupos. Parecen ocupar una posición intermedia entre los más clericales votantes de centro derecha y los generalmente anticlericales de la izquierda.

Los sentimientos hacia la Iglesia (medidos por una comúnmente usada escala punto-11 en la cual 0 representa "extrema hostilidad» y 10 «máxima simpatía) confirman estos resultados. Las puntuaciones medias del «termómetro» son las siguientes: extrema izquierda, 1,4; izquierda regional, 2,5; PCE, 2,7; PSOE, 4,8; moderados regionales, 5,7; UCD, 7,3; CD, 7,2, y extrema derecha, 6,8 .

Otro aspecto de la relación entre religión y preferencias de partidos tiene que ver con la existencia de subculturas políticas «compartamentalizadas» que no sólo son diferentes unas de otras, sino que también son percibidas como incompatibles. Las percepciones de incompatibilidad entre comunismo y catolicismo han sido estudiadas en otros países, y, dada la historia de España, no sería sorprendente encontrar este punto de vista ampliamente sostenido en algunos sectores del electorado español. Los líderes del PCE han intentado a lo largo de los últimos años cambiar la imagen de partido antireligioso $\mathrm{y}$, como hemos visto, cuidadosamente evitaron entrar en conflicto con la Iglesia durante los debates constitucionales. Podría parecer, sin embargo, que sus esfuerzos no han tenido éxito entre los votantes de centro-derecha, quienes se muestran más sensibles a los problemas religiosos (cuadro 3). La opinión de los miembros del PCE sobre este problema es, no obstante, consistente con las opiniones de los simpatizantes de los partidos de izquierda: ligeramente algo más del 50 por 100 de los simpatizantes del Partido Socialista y casi el 72 por 100 de los simpatizantes del Partido Comunista creen que es posible ser a la vez buen comunista y buen católico. Esta misma pauta general aparece, aunque de forma bastante atenuada, respecto al problema de la compatibilidad entre ser un buen socialista y un buen católico.

\section{Cuadro 3}

PORCENTAJES DE LAS OPINIONES EXPRESADAS POR LOS VOTANTES A LA PREGUNTA «PUEDE UN BUEN COMUNISTA SER UN BUEN CATOLICO?»

\begin{tabular}{|c|c|c|c|c|c|c|c|c|}
\hline & \multicolumn{8}{|c|}{ PREFERENCIA DE PARTIDO } \\
\hline & $\begin{array}{c}\text { Extrema } \\
\text { Izq. }\end{array}$ & $\begin{array}{l}\text { Izq. } \\
\text { Reg. }\end{array}$ & $\begin{array}{l}\text { Comu- } \\
\text { nistas }\end{array}$ & $\begin{array}{l}\text { Socia- } \\
\text { listas }\end{array}$ & $\begin{array}{l}\text { Reg. } \\
\text { Mod. }\end{array}$ & UCD & $C D$ & $\begin{array}{l}\text { Extrema } \\
\text { Derecha }\end{array}$ \\
\hline 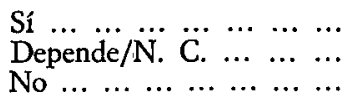 & $\begin{array}{l}47,0 \\
16,2 \\
36,8\end{array}$ & $\begin{array}{l}54,2 \\
76,3 \\
29,5\end{array}$ & $\begin{array}{l}71,9 \\
13,2 \\
14,9\end{array}$ & $\begin{array}{l}54,6 \\
20,0 \\
25,4\end{array}$ & $\begin{array}{l}33,0 \\
26,1 \\
40,9\end{array}$ & $\begin{array}{l}24,3 \\
23,0 \\
52,7\end{array}$ & $\begin{array}{r}3,6 \\
14,1 \\
72,3\end{array}$ & $\begin{array}{r}8,7 \\
10,8 \\
80,5\end{array}$ \\
\hline $\begin{array}{llllllll}N & \ldots & \ldots & \ldots & \ldots & \ldots & \ldots & \ldots\end{array}$ & $(73)$ & (120) & $(400)$ & $(1278)$ & (156) & $(1658)$ & (173) & (56) \\
\hline
\end{tabular}

En suma, por lo que hace referencia al aspecto particular considerado de los conflictos religiosos, su conexión con las tendencias partidistas es bastante pronunciada. La comparación de los datos sugiere que de hecho la relación entre los dos es incluso más fuerte en España que en ningún otro país europeo 
occidental. Ello parece ser una característica significativa del sistema de partidos español, con consecuencias a la vez para la estabilidad electoral a nivel de masas y para la flexibilidad entre las élites. El test de todo ello tendrá lugar cuando problemas tales como el aborto, el divorcio y la reforma educativa comienzen a plantearse en un futuro cercano.

\section{L A S E}

Una de las más importantes decisiones que debe ser tomada por los partidos políticos que de nuevo han surgido es la que concierne a la identidad de los grupos sociales que desean atraer como clientelas electorales estables. Numerosas opciones por lo que se refiere a las estrategias organizativas, a la penetración del partido en organizaciones secundarias y las tácticas electorales a corto plazo están estrechamente relacionadas, si no directamente derivadas, de esta básica determinación. Estas decisiones son importantes para cada partido y, consideradas conjuntamente, afectan además a la naturaleza misma del sistema de partidos. Si los partidos hubieran tenido como objetivo dirigirse a un número de grupos relativamente reducido y hubieran tenido éxito en la búsqueda de una clientela homogénea, el resultado inevitable habría sido un alto grado de polarización de clase.

La decisión sobre los grupos a los que los partidos se han de dirigir se encuentra condicionada por un cierto número de factores. El primero de ellos es la naturaleza de la estratificación social del sistema fundamentalmente, cuántos estratos identificables existen y qué amplitud tiene cada uno de ellos. El segundo tiene que ver con la imagen misma del partido, que es lo que se encuentra arraigado en su historia e ideología. Esta imagen de sí mismo puede ser modificada gradualmente; algunos aspectos pueden ser reforzados; otros debilitados, pero es muy poco probable que tal imagen pueda ser abruptamente transformada. Entre otras cosas, ello podría crear tensiones internas y ofrecer a los adversarios políticos un cómodo blanco para sus ataques. Por último, las élites están también condicionadas por la imagen de sus partidos difundidas en toda la sociedad, y éstas son demasiado difíciles de alterar en un corto espacio de tiempo.

En la campaña de 1979, los cuatro partidos españoles más importantes adoptaron estrategias notablemente similares en cuanto a la identificación de los grupos sociales que deseaban atraer. A pesar de las diferencias entre sus ideologías y sus propias imágenes, se trazaron durante la campaña amplios en lugar de reducidos objetivos y buscaron los vatos dentro de un extenso espectro de sectores sociales. Basándonos en los datos que hemos recogido; creemos que esta actitud de los estrategas de los partidos puede ser entendida a la luz de los factores que acaban de ser mencionados.

En primer lugar, todos los partidos estaban condicionados por el sistema de estratificación social. Sin duda, en las sociedades modernas ningún grupo social puede por sí mismo ofrecer el suficiente número de votos que permita a un partido jugar un rol importante. Aunque en su nivel de desarrollo España se encuentra algo más retrasada que otras naciones europeas más avanzadas, 
su estructura social ha experimentado considerables transformaciones en las dos décadas pasadas ${ }^{2 j}$. El decrecimiento del sector agrícola y el crecimiento del sector terciario han producido una importante extensión de la clase media. Además de ello, la difúsión de estilos de:vida más homogéneos en grandes sectores de la sociedad ha tendido a desdibujar las tradicionales divisiones entre clases. Por todo ello tiene poco sentido para cualquier partido mayoritario o aspirante a serlo limitar su llamamiento a un grupo relativamente pequeño. Más brevemente, la simple aritmética social contribuye a explicar por qué los cuatro partidos principales decidieron dirigirse a un amplio número de grupos sociales.

Los roles de las ideologías de los partidos y su imagen social se pueden apreciar mejor considerando a los partidos separadamente. Para UCD y CD, la ideología no presentaba dificultad. En las declaraciones ideológicas formales ambos partidos se definían a sí mismos como interclasistas.

UCD afirmaba explícitamente en su primera manifestación ideológica en enero de 1978 estar «al servicio de los distintos pueblos de España y de todos los sectores sociales, generacionales y humanos» ${ }^{24}$. En la misma línea de esta declaración, todos nuestros entrevistados de este partido afirmaban que era su deseo atraer a personas de todos los sectores sociales. Aunque frecuentemente expresaron el convencimiento de que su mayor apoyo debería encontrarse en las clases medias, añadían que deseaban ampliar esta base potencial e incluir en ella sectores importantes de la clase obrera. Así, los sucesivos llamamientos de UCD durante las elecciones generales de 1979, como describía en una entrevista después de las elecciones una estratega del partido a alto nivel, «no era un mensaje dirigido a ningún sector específico de ciudadanos, sino que estaba destinado en cierta medida a buscar el común denominador de todas las posiciones sociales, de todas las regiones de España, y por ello era muy general»».

De forma similar, los miembros de AP expresaban con frecuencia su convencimiento de que su base de apoyo más importante debería de encontrarse en las clases medias. Sin embargo, ellos también deseaban atraer amplios sectores del electorado. Por otra parte, varios de ellos relacionaban esta posición interclasista a su rechazo del concepto de clase social per se. Como uno de los miembros de AP explicaba, «nosotros no tenemos la intención de representar los intereses de ninguna clase, de ser el partido de ninguna clase en particular. No creemos en la lucha de clases».

No obstante, las fuerzas de centro-derecha tenían problemas con la imagen de UCD y $C D(A P)$ en la sociedad española. Sus dificultades a la hora de desarrollar una amplia estrategia descansaban en la creencia extensamente difundida de que los partidos de Suárez y Fraga eran. fuerzas al servicio de las clases altas. La conciencia de que su imagen social constituía un hándicap se reflejaba a menudo en nuestras entrevistas. Como un miembro de AP manifestaba, «las clases trabajadoras y las clases medias no nos apoyan porque, erróneamente,

${ }^{23}$ Consultar, por ejemplo, los datos recopilados en Estudios sociológicos sobre la situación social de España, Fundación FOESSA, 1975, especialmente, el capítulo 6, págs. 705824.

${ }^{24}$ UCD, Secretaría General de Información, Documento ideológico de UCD, Madrid, enero 1978, pág. 7 . 
creen que somos el partido del gran capital y de los empresarios, y esto no es verdad. Tenemos muchos miembros que pertenecen a profesiones liberales, pero que no pertenecen a la gran oligarquía económica. No discriminamos a nadie. Queremos atraer un mayor número de personas de la clase obrera y especialmente del sector agrícola».

Para los dos partidos principales de la izquierda, la adopción de una estrategia de objetivos amplios requería una redefinición implícita o explícita de la noción de clase obrera. El PCE había comenzado a cambiar ya desde 1956 la imagen de sí mismo bajo el liderazgo de Santiago Carrillo, y los estatutos aprobados en el Congreso del partido en 1978 se referían al PCE como «organización política de vanguardia de la clase obrera... y de las fuerzas progresistas de España. A él pertenecen voluntariamente hombres y mujeres que proceden de la clase obrera, el campesinado, las fuerzas de la cultura y otros sectores de la población» ${ }^{25}$. Un veterano e importante líder comunista nos decía: «Creemos que en nuestro partido hay hoy lugar para sectores que van desde la clase media y pequeños industriales, empresarios y comerciantes hasta los obreros.» Esta definición substancialmente ampliada de la constitución del partido fue adoptada por todos los niveles de la jerarquía del mismo y en todas las áreas geográficas. De hecho, prácticamente en todas las zonas los líderes del PCE entrevistados se referían a la «clase obrera» al describir los grupos de electores a los que ellos se dirigían, y en todos los casos, salvo en uno, ampliaban dicha descripción con una larga lista de otros grupos sociales. Probablemente las inclusiones más notorias que se hacen en la lista de los grupos a los que el PCE se dirige son la de los sectores de pequeños y medianos empresarios y la de los campesinos propietarios de la tierra ${ }^{26}$.

¿Qué grupos sociales no quería entonces el PCE atraer en la campaña de 1979? Varios entrevistados indicaron que no tenían el deseo de conseguir el apoyo de «los capitalistas». Pero la inclusión en la lista de los grupos que deseaban atraer de los sectores de pequeños y medios empresarios y los de propietarios de la tierra indica que la mera posesión de los medios de producción no implicaba, bajo su punto de vista, la inclusión en el concepto de capitalista. En la práctica, los estrategas del PCE adoptaban una definición de capitalista más pragmática, la cual incluía sólo a los latifundistas, rentistas y propietarios de empresas de más de doscientos cincuenta empleados ${ }^{27}$. Al describir los grupos que desaba captar el PCE incluía realmente a todos los sectores del electorado español salvo una minúscula proporción de él.

El Partido Socialista también se ha definido históricamente a sí mismo como un partido de las clases trabajadoras, y en fecha tan reciente como el XXVII Congreso (en diciembre de 1976) había adoptado, desde una perspec-

\footnotetext{
${ }^{25}$ PCE, IX Congreso del Partido Comunista de España, Editorial Crítica, Barcelona, 1978 , pág. 169.

r Véase PCE, IX Congreso, Resoluciones 9 y 16, págs. 103-111 y 157-162, respectivamente.

${ }^{27}$ Varios de nuestros entrevistados mencionaban este número como línea divisotia entre «capitalistas» y medianos empresarios. La resolución 16 del IX Congreso del partido parece indicar que los empresarios que tengan hasta 250 empleados deberían ser clasificados como «medianos empresarios». Véase $I X$ Congreso, pág. 158.
} 
tiva tradicional y bastante estrecha, una interpretación ideológicamente maximalista del concepto de clase trabajadora ${ }^{28}$. En 1979, la mayoría de los militantes del PSOE continuaban describiendo la clientela electoral del partido como «la clase obrera»; sin embargo, en sus definiciones prácticas quedaba claro que en realidad interpretaban el concepto muy ampliamente. De acuerdo con un líder regional del PSOE, las clases trabajadoras van «desde el decano de una facultad al estudiante, desde el profesional liberal y el ejecutivo al carpintero, pescador, labrador o albañil». Por lo demás, hicieron considerables esfuerzos para atraer el apoyo de la «clase media». La racionalización de esta estrategia era explicada por un secretario provincial de la organización del partido en Andalucía:

Después de las elecciones de 1977 realizamos una serie de estudios con el fin de conocer de qué grupos habíamos recibido apoyo. Encontramos que éste procedía de la clientela tradicional del PSOE: trabajadores industriales y trabajadores agrícolas. En las siguientes elecciones Felipe González decidió que deberíamos intentar extender la base del partido atrayendo en particular a los pequeños agricultores, empresarios y miembros de las profesiones liberales. Aunque sólo un 10 por 100 de las personas pertenecientes a estos sectores nos habían votado, pensamos que podían preferir un partido más progresista. Queremos atraer a una extensa proporción de aquellos grupos sociales sin abandonar al mismo tiempo nuestro atractivo tradicional.

En suma, los cuatro principales partidos hicieron llamamientos interclasistas intentando ampliar las bases de apoyo electoral cuanto fuera posible. Esto no significa, empero, que el PCE y el PSOE rechazaran hacer uso de sus vínculos con los sindicatos con la intención de reforzar el apoyo tradicional entre los sectores organizados de la clase obrera. Por el contrario, la mobilización de los votantes de la clase obrera por los dos sindicatos más importantes, Comisiones Obreras (CCOO) y la Unión General de Trabajadores (UGT), fue una táctica importante utilizada tanto por el Partido Comunista como por el Partido Socialista en estas elecciones.

Desde fuera estos lazos parecen cerrados e institucionalizados. Entre los miembros de UCD y AP la frase «correa de transmisión» era a menudo utilizada para describir lo que era percibido como una relación de subordinación entre el sindicato y el partido político. De hecho estas relaciones no son tan estrechas como podrían parecer; son sutiles y complejas.

La más sutil de estas relaciones es la existente entre Comisiones y el Partido Comunista de España. CCOO reivindica ser una central independiente no ligada a ningún partido específico, mientras que al mismo tiempo el PCE

28 PSOE, Resoluciones del XXVII Congreso del PSOE, Madrid, 1977. Todavía más llamativa resulta la retórica de la Declaración de Principios, que fue reafirmada en el XXVII Congreso. Véase PSOE, Declaración de Principios y Estatutos del PSOE, se encuentra asimismo reproducida en Felipe González y Alfonso Guerra, PSOE, Ediciones Alba, Bilbao, 1977, págs. 23-24. 
afirma su absoluto respeto hacia la independencia de este sindicato ${ }^{29}$. Hasta cierto punto es una afirmación real, especialmente en la medida en que no existen vínculos organizativos explícitos como los que se dan entre el Partido Laborista Británico y la Trade Union Congress. No hay puestos reservados en ninguno de los dos comités ejecutivos para los representantes del otro. Además de ello, los miembros del Partido Comunista no están obligados a pertenecer a CCOO. No obstante, las dos organizaciones mantienen en la práctica una informal pero estrecha relación que ha incidido en la orientación de las campañas electorales. En las elecciones de 1979 CCOO trazó un programa social y político que deseaba ver aplicado; dicho programa era notoriamente similar al elaborado por el PCE durante la campaña. Los líderes de CCOO pidieron a todos los miembros del sindicato «apoyar a aquellos partidos que defendían el programa»; ello suponía un apoyo indirecto al PCE ${ }^{30}$. Otra forma de mobilización de los votantes fue la inclusión de un gran número de líderes de Comisiones en las listas del PCE. Como describía uno de los dirigentes de la campaña del PCE, «lo que hicimos durante la campaña fue explotar el prestigio de Comisiones Obreras, èl prestigio de los comunistas que son líderes de CCOO. Es de esta forma como intentamos ganar el voto de los trabajadores para el Partido Comunista».

La relación entre el PSOE y la UGT es mucho más estrecha y tiene mucha más antigüedad. Los' estatutos del Partido Socialista contemplan formalmente a la UGT como el sindicato de «inspiración socialista» y obliga a todos los miembros del PSOE a afiliarse a dicho sindicato ${ }^{31}$. EI PSOE, por otra parte, interviene mucho más abiertamente que el PCE en los problemas del sindicato. En las elecciones sindicales de 1978, por ejemplo, «la socialista UGT enfatizó sus vínculos con el Partido argumentando que el Partido Socialista Obrero Español (PSOE) era la senda del futuro» ${ }^{32}$. En la campaña de 1979, las federaciones regionales y provinciales de la UGT apoyaron explícitamente a los candidatos del PSOE en la mayoría de las regiones de España. Este esfuerzo tuvo ocasionalmente efectos negativos; en algunas zonas la UGT se resintió de estar siendo utilizada de manera partidista durante la campaña y explícitamente rehusó apoyar al Partido ${ }^{33}$. No obstante, en general, la UGT trabajó activamente a favor del PSOE en la campaña de 1979.

Con independencia de la mobilización que socialistas y comunistas hicieron de los sindicatos que los apoyaban, la estrategia de las élites ayudó a desdibujar

${ }^{29}$ Véase la Resolución 7 aprobada en el IX Congreso del PCE, en IX Congreso, páginas 93-95.

${ }_{30}$ Véase Eduardo Espía, «Los medios de la campaña: la organización partidista», en Las elecciones legislativas del 1 de marzo de 1979, Ed. Jorge de Esteban y Luis López Guerra, Centro de Investigaciones Sociológicas, Madrid, 1979, págs. 184-185. Casi los mismos términos se pueden encontrat en Pedro J. Ramírez, Así se ganaron las elecciones: 1979, Editorial Prensa Española, Madrid, 1979, pág. 61.

${ }_{31}$ PSOE, Estatutos del PSOE aprobados en el XXVII Congreso, pág. 3 y att. 8 g). Esta política fue reafirmada en la Resolución sindical adoptada en el XXVII Congreso del PSOE. Véase PSOE, Resoluciones del XXVII Congreso del PSOE, 1977, pág. 5 , puntó d).

${ }_{32}$ Joe Gandelman, Spanish Unions Compete for Suport, en «The Christian Science Monitor», 17 de febrero de 1978, pág. 19.

${ }^{33}$ Véase El País, 7 de febrero de 1979, pág. 10, y Ramírez, Así se ganaron las elecciones, cit., pág. 87. 
más que a remarcar las líneas divisorias entre clases sociales. Hemos argumentado con anterioridad que una de las razones para ello se encontraba en la naturaleza objetiva de la estratificación social. Otra razón podría ser el convencimiento de las élites de que un estricto llamamiento de clase difícilmente tendría éxito entre el electorado. Nuestros datos a nivel de masas indican que éste era un punto de vista bien fundamentado.

El electorado español se manifiesta abrumadoramente a favor de que «los partidos deben representar los intereses de todas las clases sociales» (76 por 100). Entre los votantes de la izquierda resulta algo más popular un sentimiento de clase un tanto más cerrado, pero incluso en este caso dicha posición representa un punto de vista minoritario. Solamente el 34 por 100 de los simpatizantes de la extrema izquierda, el PCE y la izquierda regional están a favor de la noción de que «los partidos deberían representar los intereses de tan sólo una clase social». Por otro lado, el sentimiento de pertenecer a una clase social, prerequisito para que tenga éxito un llamamiento de clase, es compartido sólo ligeramente por algo más del 40 por 100 del electorado. El resto de los votantes o negaban estar identificados con una clase social (36 por 100) o lo desconocían.

La falta de énfasis que las élites pusieron en las líneas de división entre las clases sociales encontraron una importante correspondencia a nivel de masas. El análisis de la composición social de los diferentes grupos de simpatizantes (cuadro 4) muestra sólo una moderada relación entre el status de los votantes (o los cabezas de familia) y sus preferencias partidistas. Ciertamente, entre

\section{CUADRO 4}

NIVEL DE «STATUS» DEL ENCUESTADO O CABEZA DE FAMILIA POR PREFERENCIA DE PARTIDO (ABAJO EN PORCENTAJES)

\begin{tabular}{|c|c|c|c|c|c|c|c|c|}
\hline & \multicolumn{8}{|c|}{ PREFERENCIA DE PARTIDO } \\
\hline & $\begin{array}{c}\text { Extrema } \\
\text { Izq. }\end{array}$ & $\begin{array}{l}\text { Izq. } \\
\text { Reg. }\end{array}$ & $\begin{array}{l}\text { Comu- } \\
\text { nistas }\end{array}$ & $\begin{array}{l}\text { Socia- } \\
\text { listas }\end{array}$ & $\begin{array}{l}\text { Reg. } \\
\text { Mod. }\end{array}$ & UCD & $\mathrm{CD}$ & $\begin{array}{l}\text { Extrema } \\
\text { Derecha }\end{array}$ \\
\hline $\begin{array}{lllllll}\mathrm{I} & \ldots & \ldots & \ldots & \ldots & \ldots & \ldots\end{array}$ & 6,3 & 8,6 & 9,0 & 7,8 & 9,4 & 13,6 & 29,9 & 35,0 \\
\hline $\begin{array}{lllllll}\text { II } & \ldots & \ldots & \ldots & \ldots & \ldots & \ldots\end{array}$ & 36,1 & 31,5 & 19,6 & 20,0 & 22,4 & 15,6 & 29,8 & 22,4 \\
\hline $\begin{array}{lllllll}I I I & \ldots & \ldots & \ldots & \ldots & \ldots & \ldots\end{array}$ & 6,4 & 17,1 & 9,3 & 11,9 & 18,7 & 17,6 & 17,7 & 18,8 \\
\hline $\begin{array}{lllllll}\text { IV } & \ldots & \ldots & \ldots & \ldots & \ldots & \ldots\end{array}$ & 9,8 & 6,4 & 7,7 & 8,0 & 9,5 & 6,8 & 4,3 & 7,9 \\
\hline $\begin{array}{lllllll}V & \ldots & \ldots & \ldots & \ldots & \ldots & \ldots\end{array}$ & 2,7 & 3,1 & 3,7 & 5,6 & 4,4 & 12,4 & 3,7 & 2,9 \\
\hline $\begin{array}{lllllll}\mathrm{VI} & \ldots & \ldots & \ldots & \ldots & \ldots & \ldots\end{array}$ & 22,3 & 17,6 & 27,2 & 22,7 & 21,0 & 11,8 & 4,6 & 6,9 \\
\hline $\begin{array}{llllllll} & \ldots I I & \ldots & \ldots & \ldots & \ldots & \ldots\end{array}$ & 15,1 & 9,7 & 18,7 & 19,7 & 8,9 & 13,7 & 4,7 & 0,4 \\
\hline Other $/$ N. A. ... ... ... ... & 1,2 & 6,0 & 4,8 & 4,3 & 5,8 & 8,5 & 5,3 & 5,9 \\
\hline $\begin{array}{lllllllll}N & \ldots & \ldots & \ldots & \ldots & \ldots & \ldots & \ldots\end{array}$ & (73) & (120) & $(400)$ & $(1278)$ & (156) & $(1658)$ & (173) & (56) \\
\hline
\end{tabular}

La composición de los siete grupos de status es la siguiente:

I: Empresarios, profesionales, terratenientes, altos ejecutivos públicos y privados.

II: Nivel medio de empleados públicos y privados, profesiones técnicas.

III: Propietarios, pequeños empresarios, artesanos independientes.

IV: Nivel bajo de funcionarios, vendedores y. superyisores de personal. . .

V: Pequeños agricultores.

VI: Trabajadores agrícolas e industriales cualificados.

VII: Trabajadores agrícolas e industriales no cualificados. 
los electores del PCE y $\mathrm{CD}$, aquellos que provienen de los estratos sociales alto y bajo se encuentran fuertemente representados. Globalmente las diferencias de status social entre los diferentes grupos de simpatizantes tienden, sin embargo, a ser bastante reducidas. Ello es particularmente cierto en el caso de los dos partidos principales. Aparecen algunas diferencias entre la base social de UCD y el PSOE: dentro de las categorías de este último, los industriales y los trabajadores ocupan una posición más prominente que en UCD $(42,5$ por 100 vs. 25,5 por 100$)$. Por el contrario, agricultores, $y$ en menor medida personas pertenecientes a la clase media, se encuentran más fuertemente representadas en el partido del Gobierno que entre los socialistas. A pesar de ello, comparando la composición social del PSOE y de UCD, resultan más llamativas sus similitudes que sus diferencias.

Que ningún partido monopoliza el apoyo de ningún estrato social es algo que queda claramente demostrado en el cuadro 5. Inclusive en los estratos sociales más bajos se incluye un considerable número de votantes de UCD. De manera semejante, más del 30 por 100 de los dos estratos superiores inclinan sus simpatías hacia la izquierda. Esto confirma una vez más la debilidad de la relación entre la identificación de clase y la elección partidista. No es sorprendente, no obstante, que la identificación subjetiva con una clase se encuentre estrechamente relacionada con el nivel de fidelidad de los votantes. Como en otros países, la conciencia de clase tiende a ir en paralelo al apoyo a los partidos de izquierda. Comunistas, socialistas y otros votantes de izquierdas se inclinan posiblemente más que otros encuestados a mantener a la vez un sentimiento de identificación de clase y una identificación con la clase obrera. En todas aquellas zonas en las que alrededor de un 50 por 100 de los electores de los partidos de izquierda sienten pertenecer a la clase obrera, alrededor de un 80 por 100 de los votantes del centro-derecha no tienen conciencia de clase o se identifican con la clase media.

\section{CUADRO 5}

«STATUS» Y PREFERENCIA DE PARTIDO (TRANSVERSALMENTE EN PORCENTAJES)

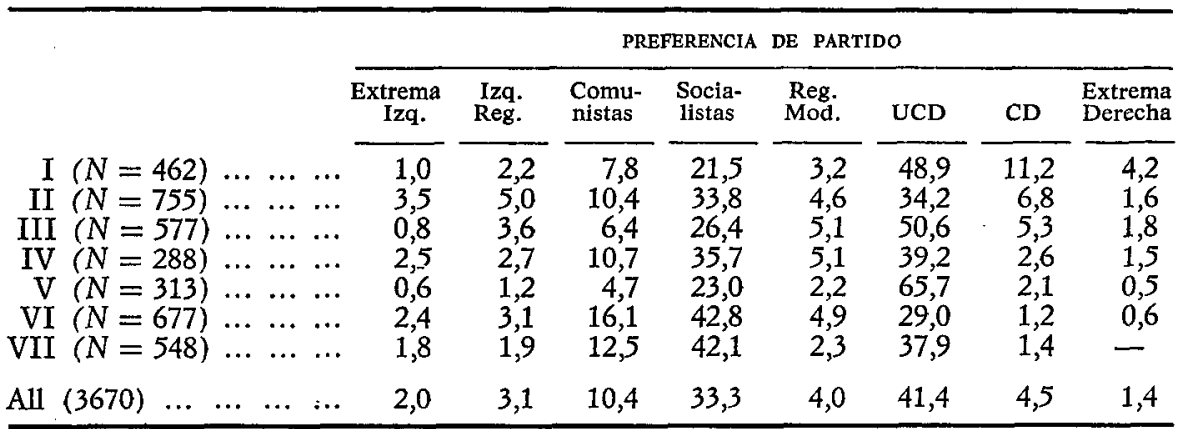

Nota: Véase Cuadro 4 para la descripción de los grupos de status. 
Los datos a nivel de masas sobre afiliación a los sindicatos y preferencia de partido confirman la existencia del alineamiento entre partidos y sindicatos que hemos tratado anteriormente. Como era de esperar, los miembros de los sindicatos votan muy preferentemente por los partidos de izquierda (84 por 100). La elección del partido se encuentra a su vez claramente relacionada con la pertenencia a uno u otro de los sindicatos mayoritarios. El 90 por 100 de los miembros de UGT votan a favor del PSOE, y el 67 por 100 de los afiliados a CCOO votan por el PCE. Los sindicatos parecen ser así un instrumento efectivo para crear y reforzar los vínculos entre sectores del electorado y los partidos. No obstante ello, su utilidad es reducida dada la aparentemente limitada penetración de los sindicatos en la sociedad española. En nuestra muestra sólo un 11 por 100 del electorado declaraba estar afiliado a un sindicato, y una idéntica proporción de afiliación ha sido recientemente puesta de manifiesto por otros investigadores ${ }^{34}$.

En conjunto, los esfuerzos de la élite para atraer amplios sectores sociales han encontrado un relativo éxito. Nuestros datos sobre la identificación subjetiva con una clase sugieren que las imágenes con las que las personas asocian mentalmente a cada partido está más fuertemente correlacionada con la preferencia electoral que lo está la posición social objetiva. También a este respecto la política de masas en España resulta diferente a las de otros países europeos occidentales.

\section{REG I O N}

La España de hoy es un Estado para todos los españoles, un Estadonación para una gran parte de la población y sólo un Estado, pero no una nación, para importantes minorías ${ }^{35}$.

Durante la II República, el conflicto acerca de cómo organizar el Estado español y qué lo constituía realmente, fue violento y contribuyó en gran medida al estallido de la guerra civil española. Con la muerte de Franco y el resurgimiento de la democracia, el conflicto ha reaparecido en su forma más virulenta, causando sólo en 1978 y 1979 la muerte de más de 240 personas. Así, la existencia de sentimientos nacionalistas y su expresión articulada en diversas demandas (que van de una limitada autonomía regional al federalismo y a una total independencia para ciertas minorías) continúa siendo una de las principales fuentes del conflicto no sólo en la sociedad española globalmente considera$\mathrm{da}$, sino también dentro de las diferentes regiones del país. Como resultado de este conflicto y su nuevo reforzamiento, en lugar de un único sistema de partidos encontramos varios, en los cuales los partidos de carácter estatal como UCD y PSOE compiten en la búsqueda de apoyo con partidos o coaliciones

${ }^{34}$ Peter McDonough, Antonio López Pina y Samuel H. Barnes, The Spanisb Public in Political Transition, British Journal of Political Science (de próxima aparición).

${ }_{35}$ Juan J. Linz, «Early State-Building and Later Peripheral Nationalism Against the State: The Case of Spain», en Building State and Nations, Ed. S. N. Eisenstadt y Stein Rokkau (Beverly Hill: Sage Publications, 1973), pág. 99. 
regionales, como los moderados Partido Nacionalista Vasco (PNV) y Convergència $i$ Unió (CIU) y los más extremistas Herri Batasuna, Euskadiko Ezkerra y el Bloque Nacional del Pueblo Gallego (BNPG).

A pesar de que entre las elecciones parlamentarias de 1977 y las de 1979 el número de partidos relevantes de carácter estatal quedó reducido a cuatro, a nivel regional tanto la fragmentación como la polarización se han intensificado. En muchas regiones, la competición se establece no sólo entre los partidos estatales y regionales, sino también entre los grupos más moderados y más radicales de los últimos. Por otra parte, a pesar de la promulgación de una Constitución que reconocía la existencia de las nacionalidades, de la concesión de autonomía al País Vasco y a Cataluña en 1979 y de la apertura de negociaciones entre Madrid y otras regiones, la politización del problema regional no ha disminuido. En cada una de las sucesivas elecciones que han tenido lugar desde 1977, los partidos regionales, y los más radicales de éstos en el País Vasco, han ampliado su apoyo popular a expensas de los partidos estatales. El incremento de la polarización por lo que hace a la cuestión regional es una tendencia preocupante. Por ello, de qué forma el conflicto regional sea integrado dentro del sistema de partidos actualmente en proceso de desarrollo será crucial para el futuro de la democracia española.

Esta cuestión resulta particularmente importante en aquellas tres regiones de España -Euzkadi, Cataluña y Galicia - que históricamente han expresado sus deseos de autogobierno regional o de independencia. Los habitantes de estas zonas son distintos de la población dominante en etnicidad, lengua y cultura. Más aún, como demuestra el cuadro 6, en estas tres regiones, especialmente en la zona vasca, considerables minorías o no se identifican del todo con España o se sienten vinculadas más fuertemente a su propio grupo nacional que a España. Cantidades substanciales de nacidos vascos o catalanes en particular manifiestan un sentimienio exclusivo de lealtad a su propio grupo: el 51 por 100 entre los nacidos vascos y el 20 por 100 entre los nacidos catalanes.

CuAdro 6

PORCENTAJE DE POBLACION QUE EXPRESA

UNA IDENTIFICACION NACIONAL SUBJETIVA POR REGION

\begin{tabular}{|c|c|c|c|}
\hline & País Vasco & Cataluña & Galicia \\
\hline 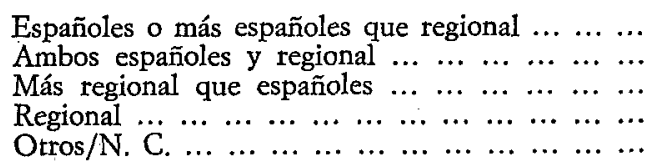 & $\begin{array}{r}26 \\
22 \\
10 \\
34 \\
8\end{array}$ & $\begin{array}{r}34 \\
33 \\
11 \\
13 \\
9\end{array}$ & $\begin{array}{r}21 \\
43 \\
11 \\
24 \\
2\end{array}$ \\
\hline $\begin{array}{lllllllllllllll}N & \ldots & \ldots & \ldots & \ldots & \ldots & \ldots & \ldots & \ldots & \ldots & \ldots & \ldots & \ldots & \ldots & \ldots\end{array}$ & (929) & $(1.232)$ & $(520)$ \\
\hline
\end{tabular}

Las variaciones en el grado de identificación nacional subjetiva entre los tres grupos regionales pueden sólo verse parcialmente explicadas por la amplitud de las diferencias objetivas que los distinguen de la población dominante. 
Por ejemplo, tan sólo una proporción relativamente pequeña de nacidos vascos afirman hablar su lengua regional (un 30 por 100 comparado con un 96 por 100 de los nacidos en Cataluña y un 81 por 100 de gallegos ${ }^{36}$; a pesar de ello, es entre los vascos donde los sentimientos nacionales son más fuertes. De manera similar, las variaciones que aparecen entre los grupos regionales en la expresión de la lealtad a sus propios grupos no son suficientes, como veremos, para explicar las diferencias de grado en que expresan sus preferencias por la autonomía regional, el federalismo o la independencia. Si bien no resulta sorprendente que los vascos (quienes muestran el grado de identificación más bajo con España) deban ser el principal problema de un Estado español centralizado, sí lo es, en cambio, que los gallegos (quienes expresan sólo un grado ligeramente menor de identificación como grupo) sean relativamente inactivos en sus reivindicaciones de autonomía regional.

Numerosos factores explican las variaciones de grado en que las diferencias objetivas y subjetivas se han politizado. Entre tales factores tienen relativa importancia otros problemas como clase y religiosidad, el nivel y la naturaleza del desarrollo económico y el grado de mobilización social de la población. Igualmente, juegan roles importantes la organización e ideología de los partidos, especialmente en la medida en que ellos articulan los sentimientos nacionalistas y la mobilización de masas en orden a apoyar las demandas expresadas por tales sentimientos. Defenderemos, en suma, que las creencias y actitudes de las élites de los partidos constituyen una variable independiente importante a la hora de determinar si y hasta qué grado las tensiones centro-periferia se cargan de contenido político.

En las tres regiones, los partidos estatales compiten con los partidos regionales con respecto tanto a sus posiciones en el problema nacional cuanto a los problemas tradicionales izquierda-derecha. En la mayoría de los casos, los partidos que son más extremistas (independentistas) en la primera de las categorías - como los vascos Herri Batasuna y Euskadiko Ezkerra, el gallego Bloque $\mathrm{Na}$ cional del Pueblo Gallego (BNPG) y el catalán Bloc d'Esquerra d'Alliberament Nacional (BEAN) - tienden también a ser más radicales (izquierdistas) en la segunda. Los partidos estatales, si bien suelen ser caracterizados por las élites de los partidos regionales como centralistas o con el término más despectivo de sucursalistas, todos — desde CD al PCE - apoyan la autonomía regional. La defienden, no obstante, en grados diferentes y con diverso énfasis programático.

Aun cuando es cierto que la posición a favor de la autonomía del PCE y del PSOE es más pronunciada que la de los partidos de centro-derecha, ésta se encuentra, no obstante, moderada por el conflicto percibido entre los problemas de clase versus los problemas nacionales y por la importancia que tiene en Euzkadi y Cataluña mobilizar el apoyo de la clase obrera inmigrante. Así, al mismo tiempo que Txiki Benegas, líder del PSOE en el País Vasco, rechazaba la descripción de su partido como centralista («los socialistas somos los auténticos autonomistas... porque somos los únicos que hemos defendido,

${ }^{36}$ Salustiano del Campo, Manuel Navarro y Félix Tezanos, La cuestión regional española, Editorial Cuadernos para el Diálogo, S. A., Madrid, 1977, págs. 195, 212 y 227. 
y continuaremos haciéndolo, el Estatuto de Guernica a la vez contra el centralismo de UCD y contra las tendencias independentistas que en mayor o menor medida se manifiestan en Herri Batasuna, en el PNV y en Euskadiko Ezkerra») ${ }^{37}$, lamentaba que el «problema nacional hubiera ensombrecido los problemas de clase» ${ }^{38}$. Para UCD y CD, la preocupación por mantener la unidad de España como un único Estado-nación, junto al miedo de un incremento de las divisiones sociales como resultado de la autonomía, ha imposibilitado un apoyo absoluto de un sustancial autogobierno regional. La mayor objeción de Fraga, mantenida en una entrevista por escrito y repetida por las élites regionales de $C D$, a la inclusión del término nacionalidades en el artículo 2 de la Constitución se basa en que «una nación no puede existir dentro de otra nación».

Sin embargo, los líderes provinciales de los partidos estatales en estas regiones tienden a mostrar más simpatías ante las demandas regionales que sus compañeros del resto de España, en parte sin duda porque ellos mismos son miembros de un grupo regional particular y en parte porque deben mostrarse más sensibles al problema si esperan competir con éxito con los partidos regionales.

A pesar de las similitudes básicas en sus sistemas regionales de partido, el País Vasco, Cataluña y Galicia difieren entre ellos en varios aspectos importantes: 1) el grado de polarización y fragmentación por lo que hace referencia a la cuestión de la nacionalidad; 2) hasta qué punto tales divisiones coinciden con diferencias en el espectro izquierda-derecha, y 3) la fuerza relativa de cada tipo de partido.

\section{EL SISTEMA DE PARTIDOS VASCO}

El sistema de partidos vasco resulta el más complejo con respecto a cada uno de los siguientes criterios. Primero, los partidos regionales son crecientemente dominantes en el País Vasco. En las elecciones de las Cortes Constituyentes de 15 de junio de 1977 todos los partidos regionales recibieron un total de 36,5 por 100 de los votos. En las elecciones parlamentarias de 1979 su porcentaje de voto creció a un 49,7 por 100. En las más recientes elecciones regionales, en marzo de 1980, la combinación de sus votos totalizaba el 64,5 por 100 . Aunque de hecho el PNV continúa acumulando una mayoría de los votos que van a los partidos regionales, a la vez que siendo el partido que más votos consigue del total emitido en cada elección, el apoyo a los partidos regionales se está dividiendo y polarizando crecientemente entre el moderado PNV, de un lado, y los partidos radicales abertzales, Herri Batasuna y Euskadiko Ezkerra, de otro. En las elecciones de 1977, el PNV obtuvo un 30,1 por 100 del total de los votos emitidos y Euzkadiko un 6,4 por 100 (Herri Batasuna no existía en ese momento). En las elecciones parlamentarias de 1979 (durante la cuales Herri Batasuna presentaba por primera vez candidatos); las cifras

${ }^{37}$ El País, 30 de marzo de 1980, pág. 11.

${ }^{38}$ Informaciones, 19 de noviembre de 1979, pág. 5. 
comparadas eran de 27,1 por 100 y 22,6 por 100. En las últimas elecciones, el PNV alcanzó un 38,1 por 100 y Herri Batasuna y Euskadiko Ezkerra juntos alcanzaron un 26,4 por 100 de los votos.

Lo más sorprendente de este crecimiento de votos en favor de la izquierda abertzale es que la mayoría de este aumento fue conseguido por Herri Batasuna, el más extremista de los dos, una coalición de marxistas-leninistas y de otros grupos separatistas. Defendieron el voto negativo en el referéndum constitucional porque, según los líderes de Herri Batasuna, ni se reconocía la soberanía nacional vasca ni se consideraba a Navarra como parte de la nación vasca. Aunque en todas las elecciones desde marzo de 1979 ha presentado candidatos (algunos de los cuales estaban en prisión), sus representantes elegidos rechazaron tomar posesión de sus escaños tanto en el Parlamento central como en el regional. Más importante aún: aunque el partido basa su estrategia en la lucha política, ello «no significa», según el líder de Herri Batasuna Francisco Letamendía, «el rechazo de ninguna forma de lucha que suponga un avance para el pueblo». ${ }^{39}$. De esta forma, pues, no renuncia a la violencia como una vía de conseguir sus objetivos. De hecho Herri Batasuna tiene vinculaciones con ETA militar, el ala más extremista de la organización terrorista vasca.

Al igual que hiciera Herri Batasuna, Euskadiko Ezkerra propugnó un voto negativo a la Constitución. De manera similar, tiene como objetivos el estudio obligatorio de la lengua vasca, la amnistía total para los presos políticos, la retirada de las fuerzas de la policía controlada desde Madrid del territorio vasco y el apoyo a los conciertos económicos (control regional sobre la recaudación de los impuestos y su gasto). A diferencia de Herri Batasuna, Euskadiko Ezkerra defendió, sin embargo, el voto afirmativo al Estatuto de Autonomía, y aquellos de sus miembros que resultaron elegidos han jugado un activo papel en las tareas parlamentarias tanto en Euskadi como en Madrid. La razón para ello es, según el líder de EE Mario Onaindía, que la existencia del estatuto y de un órgano representativo no constituyen por sí mismos «ni la libertad ni la auténtica democracia por la cual estamos luchando... (pero son) un instrumento válido para los trabajadores a través del cual conseguir un progresivo desarrollo del Estatuto, mejorar las condiciones de vida de la clase obrera y conseguir la necesaria modernización de la industria vasca» ${ }^{40}$. No obstante, para el partido, como Onaindía ha señalado en numerosas ocasiones, la autonomía regional es tan sólo un objetivo a corto plazo: «Hoy luchamos por la autonomía y mañana lo haremos por la soberanía y la autodeterminación de Euskadi $\gg{ }^{41}$.

El más moderado de los partidos regionalistas vascos tanto por lo que hace referencia a la cuestión nacional como a los problemas izquierda-derecha es el PNV. Fue el principal arquitecto del Estatuto de Guernica. A diferencia de Herri Batasuna y Euskadiko Ezkerra, no reivindicó la liberación y la amnistía total para los presos de ETA, no insistió en la inclusión de Navarra en la región vasca y optó, cuando menos a corto plazo, por la cooficialidad

${ }^{39}$ El País, 11 de febrero de 1979, pág. 5.

${ }^{40}$ El País, 4 de marzo de 1980 , pág. 19.

${ }^{41}$ El País, 20 de febrero de 1979, pág. 17. 
del vasco y el castellano y por la libertad de elección entre los dos como lengua de enseñanza. A la vez, sin embargo, las caracterizaciones que del PNV hacen los partidos estatales como partido que abriga tendencias separatistas parecen encontrarse confirmadas por ciertas actitudes del PNV y de muchos de sus líderes. EI PNV, por ejemplo, propugnó una abstención activa sobre la Constitución; sin embargo, al final aprobó el Estatuto de Autonomía, el cual, efectivamente, transfería un número importante de competencias a los gobiernos regionales. La ambivalencia del PNV por lo que respecta a sus objetivos a largo plazo queda reflejada en las declaraciones llevadas a cabo por su élite. El ejemplo más significativo se puede encontrar en las manifestaciones de un alto cargo del partido:

La nación vasca consiste en cuatro provincias en España y tres en Francia. Somos conscientes, no obstante, de la escasa posibilidad de unificación de este territorio a corto plazo. Sin embargo, estamos a favor de su unificación a largo plazo. Ello lo entendemos en el contexto de una Europa unida.

$Y$ - -añadió a continuación- «nosotros no somos independentistas».

La ambigüedad del PNV es asimismo notable en las declaraciones en su élite por lo que respecta al terrorismo de ETA. Un miembro del PNV, cuando se le preguntó por el terrorismo, replicó:

Recuerdo perfectamente a los patriotas franceses que lucharon contra Pétain... Entonces se les llamó terroristas. El Gobierno de Vichy hablaba de terroristas. Hoy se les llama patriotas. Por tanto, cada cosa es relativa. Ellos hablan del terrorismo de ETA; sin embargo, yo nunca hablaría de ETA como terrorista.

$\mathrm{Y}$ siguió diciendo:

Debemos tener presente que ETA fue una consecuencia de la violencia del régimen de Franco, pero, aun cuando ello es así, no es una justificación suficiente para sus acciones actuales. Sin embargo, en la medida en que el Estado español no determine medidas claras y efectivas que entren en la discriminación contra la cultura vasca, será muy difícil para nosotros poder explicar a ETA por qué deben deponer sus armas.

No inesperadamente, los partidos estatales eran menos autonomistas que los partidos regionales. A pesar de ello, todos estaban a favor de un cierto grado de autonomía regional. Durante las elecciones de 1979 todos los partidos, excepción hecha de UCD, se presentaron bajo una etiqueta - Partido Socialista de Euskadi, Partido Comunista de Euskadi y Unión Foral del País Vasco (CD) - que intentaba sugerir una imagen más regional a los votantes. Todos hicieron en sus campañas llamamientos específicos dirigidos a conseguir el apoyo de la población nativa, aunque los dos partidos de izquierda estaban condicionados en este sentido por sus deseos de atraerse a los trabajadores 
inmigrantes. De hecho, en el caso del PSOE, la pérdida de votos en las elecciones parlamentarias de 1979 fue atribuida por un miembro del partido a su fracaso a la hora de responder adecuadamente al "problema específico de Euskadi». Los cuatro partidos mantuvieron una posición similar en su defensa de la educación bilingüe, aunque tanto UCD como $C D$ defendieron que a nivel de educación universitaria la lengua de enseñanza debería ser el castellano en todos aquellos cursos que no fueran de cultura o lengua. Paradójicamente, fueron estos dos partidos los que estuvieron a favor de los conciertos económicos, a los que el PCE y el PSOE se opusieron. Como un dirigente del PCE explicaba: «Por sí mismos los conciertos económicos no resolverán nada. No existe ninguna razón por la que debamos tener ningún privilegio histórico en estas provincias... No vamos a eludir nuestras responsabilidades de compensación y solidaridad con otras provincias de España.» Así, las preocupaciones de los dos partidos de izquierda por las desigualdades de España en su conjunto restringió su capacidad de apoyo a un importante aspecto de las reivindicaciones de la autonomía vasca. Paralelamente, el énfasis de UCD y CD en el mantenimiento de la unidad de España limitó su capacidad para apoyar otra característica esencial de los sentimientos nacionalistas vascos: el reconocimiento de la. legitimidad de los «derechos históricos» del pueblo vasco, los fueros con sus consecuentes implicaciones en el derecho a la autodeterminación. Como un miembro de UCD señaló, «estamos a favor de la igualdad de las regiones, pero nos oponemos a la reivindicación del PNV de que esta zona tenga especiales derechos históricos. Esos derechos históricos han sido superados por el paso mismo de la historia». CD adoptó una posición contradictoria a este respecto. Tal y como la denominación de su partido en el País Vasco había pretendido sugerir, propugnaba la «defensa de los fueros, pero dentro de la unidad de España». Esta posición implícitamente contradictoria podría ser explicada por. el deseo de $C D$, formulado por varios entrevistados, de recoger los votos de los carlistas tradicionales, un grupo identificado históricamente con el apoyo a los fueros contra un'Estado español centralizado, liberal y secular.

\section{EL SISTEMA DE PARTIDOS CATALAN}

El sistema de partidos catalán, comparado con el vasco, se encuentra mucho menos polarizado en torno al problema del nacionalismo. Como observaba un miembro de Convergència Democràtica de Catalunya (el grupo catalán mayoritario dentro de Convergència $i$ Unió), «el nacionalismo catalán es fundamentalmente diferente del nacionalismo vasco... Nunca habrá una ETA asociada a nuestro movimiento. Ese no es nuestro estilo». A diferencia del País Vasco, en ninguna elección, con excepción de las del Parlamento regional, consiguieron los partidos regionalistas, incluso sumando sus porcentajes, una mayoría de votos en Cataluña. El grupo regional dominante, Convergència, alcanzó entre un 16 y un 19 por 100 de los votos emitidos en las tres elecciones que se celebraron entre junio de 1977 y abril de 1979. Esquerra Republicana tan sólo alcanzó un 4 por 100 en cada una de estas tres elecciones, y el partido catalán más radical, BEAN, consiguió sólo un apoyo minúsculo (menos del 2 por 100 
del voto). Aunque en las elecciones regionales de marzo de 1980 Convergència se alzó con uná mayoría de votos (28 por 100$)$-imponiéndose al PSOE, que previamente había sido el partido mayoritario- y Esquerra aumentó su nivel de apoyo a un 9 por 100, los partidos estatales siguieron siendo todavía predominantes. De hecho, lo que resulta más llamativo sobre Cataluña comparado con el País Vasco es el satisfactorio grado de penetración de los partidos de nivel estatal, y en particular de los de izquierda, a pesar de lo ampliamente arraigados sentimientos nacionalistas.

Este contraste puede ser parcialmente explicado por la gran autonomía con que cuentan las organizaciones regionales de los partidos estatales en Cataluña si se las compara con las organizaciones de los partidos en otros lugares de España. El Partido Comunista de Cataluña (PSUC) ofrece un ejemplo de ello. Los partidos estatales han tenido al mismo tiempo más éxito al asumir la identidad regional por medio de fusiones con grupos regionales. Con anterioridad a las elecciones parlamentarias de 1979 , por ejemplo, dos partidos socialistas regionales; el PSC $(\mathrm{R})$ y el PSC(C), se fusionaron con el PSOE y en la actualidad constituyen el sector dominante en la dirección de este partido. Significativa fue también la aparición en las elecciones de 1979 de un prominente regionalista catalán, Antón Canyellas, a la cabeza de UCD (la cual incluso no se autodenominó UCD, sino Centristas de Catalunya (CC/UCD). Asimismo, el bajo grado de polarización del problema nacional en Cataluña podría quizá también ser explicado por el hecho de que, a diferencia de en el País Vasco, los catalanes nativos y los emigrantes con una inclinación hacia la izquierda no tienen una alternativa comparable a Euskadiko Ezkerra y a Herri Batasuna. Probablemente también la relativa modernización del nacionalismo catalán y el grado menos intenso de polarización entre partidos regionales y estatales tenga que ver con la ausencia en las reivindicaciones actuales del nacionalismo catalán del concepto de «derechos históricos» y sus consecuentes implicaciones para la soberanía nacional. Así, aunque en varias ocasiones miembros de UCD tachaban a Convergència y a Esquerra de partidos separatistas, al contrario de en el caso del PNV, en las declaraciones de las élites de Convergència sobre sus aspiraciones de autonomía regional dentro de los límites establecidos por la Constitución ha habido poca ambigüedad. Como señalaba un entrevistado de CDC: «La ideología de este partido es una ideología nacional. Pero no queremos desgajar a Cataluña. Queremos mantener nuestra solidaridad con otras regiones de España.»

Las élites políticas catalanas parecían demostrar un consenso sustancial sobre la naturaleza y la forma deseable de la autonomía regional. Incluso la política con respecto a una dimensión tan importante del catalanismo como la lengua (un líder de CDC decía: «La lengua es la 'razón de ser'. Es el núcleo de nuestra identidad y la configuración de nuestro pueblo.»). Sólo produjo un ligero desacuerdo entre nuestros entrevistados. La élite de Convergència, como era dado esperar, se declaraba más a favor del estudio obligatorio del catalán para todos, y al final del uso exclusivo del mismo en la enseñanza. Sensibles, sin embargo, a los problemas que ello podría significar a los inmigrantes, optaron por reconocer a corto plazo la posibilidad de elegir entre las dos lenguas. Las élites del PSUC y del PSOE propugnaron un estatuto de cooficialidad 
del catalán y el castellano y la obligatoriedad del estudio del primero en la enseñanza primaria. De nuestros entrevistados sólo los de UCD se declaron opuestos a ello. Como un miembro de UCD manifestaba: «No debemos considerar la lengua castellana como una lengua extranjera tal y. como hacen algunos nacionalistas... Es una aberración que no debemos aceptar.»

En Cataluña existían, ciertamente, diferencias entre los partidos de carácter estatal y los partidos regionales con respecto al problemá nacional. Sin embargo, tales diferencias resultaban bastante ténues si se las comparaba con las que concurrían en el País Vasco. En la mayoría de los casos, los aspectos socioeconómicos e ideológicos parecían producir mayores divisiones.

\section{EL SISTEMA DE PARTIDOS GALLEGO}

El sistema de partidos gallego es el menos politizado de los tres por lo que hace a las demandas de autonomía regional. Comprende dos grupos regionales, uno más moderado que incluye a la vez a partidos socialistas y centristas nacionalistas (Unidade Galega) y el más extremista Bloque Nacional del Pueblo Gallego (BNPG). En las elecciones parlamentarias de 1977, el apoyo a estos dos grupos se encontraba equitativamente dividido; alcanzaron sólo alrededor del 5 por 100 del total de votos emitidos. En las elecciones parlamentarias de 1979, el apoyo conseguido por ambos creció, pero incluso en esta ocasión sólo consiguieron un 11 por 100 del total de votos. Los partidos estatales, muy en particular UCD y CD, continuaban dominando el sistema de partidos de Galicia. Fue de hecho debido a la fuerza parlamentaria con que contaba UCD la razón por la que la mayoría de los otros partidos rechazaron un estatuto de preautonomía para Galicia, en cuya elaboración UCD jugó el principal papel ${ }^{42}$. Unidade Galega en particular se opuso al estatuto por esta causa: «impide un nivel mínimo de autogobierno, aleja de las menos de las futuras instituciones autónomas el poder económico necesario para poder poner fin a la dependencia y al subdesartollo. Y como resultado de ello condena en el futuro al gobierno autónomo a no tener popularidad y. carecer de prestigio» ${ }^{43}$.

Unidade Galega y los partidos estatales de ịquierda coinciden en gran medida en la forma y la naturaleza deseable de la autonomía regional. Los tres pensaban que Galicia debía conseguir el grado más alto de autogobierno permitido por la Constitución. No obștante, Unidade Galega y el BNPG se mostraban a largo plazo a favor de un Estado federal español o incluso niveles más elevados de autonomía.

La posición de los partidos estatales de centro-derecha en cuanto a la autonomía para Galicia iban de la ambigüedad, por un lado, a la denuncia total, por otro. Un miembro de UCD resumía la posición del partido muy sucintamente: «Nosotros no tenemos política sobre la autonomía regional. Algunos están a su favor, otros en contra.» Un alto dirigente de $C D$ se manifestaba

12 Informaciones, 19 de diciembre de 1979, pág. 6.

*3 El País, julio de 1979. 
de forma más rotunda: «En Galicia no hay nacionalismo popular, sino nacionalismo de una élite intelectual..., el cual, en la medida en que esté preocupado por la defensa de la cultura y la lengua gallega..., me parece espléndido.» Entonces comenzó a denunciar las aspiraciones de una autonomía política para Galicia o cualquier otra región de España.

El punto en el que todas las élites de los partidos coincidían era la dificultad para mobilizar a la población gallega detrás tanto de problemas regionales como de clase. Todos mencionaban para explicarlo la persistencia del caciquismo, en especial en las áreas predominantemente rurales, la dispersión de la población, su falta de educación y familiaridad con la democracia y su tradicional conservadurismo social y político. El miembro de $\mathrm{CD}$ antes citado ofrecía probablemente la explicación más penetrante del bajo nivel de politización del problema nacional a nivel de masas:

El nacionalismo no está políticamente representado como en Cataluña y en la región vasca, donde la gente puede votar nacionalista y a la vez de acuerdo con su ideología. Mientras que aquí aquel que quiera votar nacionalista tiene que hacerlo por una determinada ideología, porque ni el centro, ni la derecha, ni incluso el Partido Socialista... son nacionalistas. Por esto muchas personas se ven obligadas a dar un salto ideológico para poder dar su voto a un partido gallego.

Esta explicación remarca claramente la importancia de los partidos políticos y sus ideologías como una determinante independiente del grado y la naturaleza del apoyo a nivel de masas del autogobierno regional.

\section{CONFLICTOS REGIONALES A NIVEL DE MASAS}

Las diferencias inter e intra regionales entre las élites corren parejas a profundas divergencias de opinión a nivel de masas, en especial por cuanto se refiere a las diversas preferencias del nivel de autonomía regional. El País Vasco, Cataluña y Galicia, además de el resto de España, se encuentran divididos en cuanto al grado de autogobierno regional deseable. Aunque la opción elegida más frecuentemente en todas las zonas de España es la autonomía regional -preferencia que concuerda con las recientes vías por las que a este respecto se está desarrollando la Constitución-, un extenso número de personas a lo largo de todo el país expresaron sus preferencias por el status quo (un Estado centralizado), el federalismo o una independencia total en ciertas regiones (véase cuadro 7). La polarización es más pronunciada en el País Vasco, donde una cuarta parte de los encuestados expresaron un deseo de independencia, y casi una quinta parte en el extremo opuesto se manifestaba a favor de un Estado centralizado. La menos polarizada es Cataluña, aunque incluso allí el centralismo y la independencia son opciones preferidas por importantes minorías. También en Galicia la opinión se encuentra dividida. No obstante, en esta región más personas se manifiestan a favor de un Estado centralizado que a favor de formas muy elevadas de autogobierno regional. 
PREFERENCIAS POR LO QUE RESPECTA A LA AUTONOMIA REGIONAL POR REGION $Y$ PREFERENCIAS PARTIDISTAS (EN PORCENTAJES)

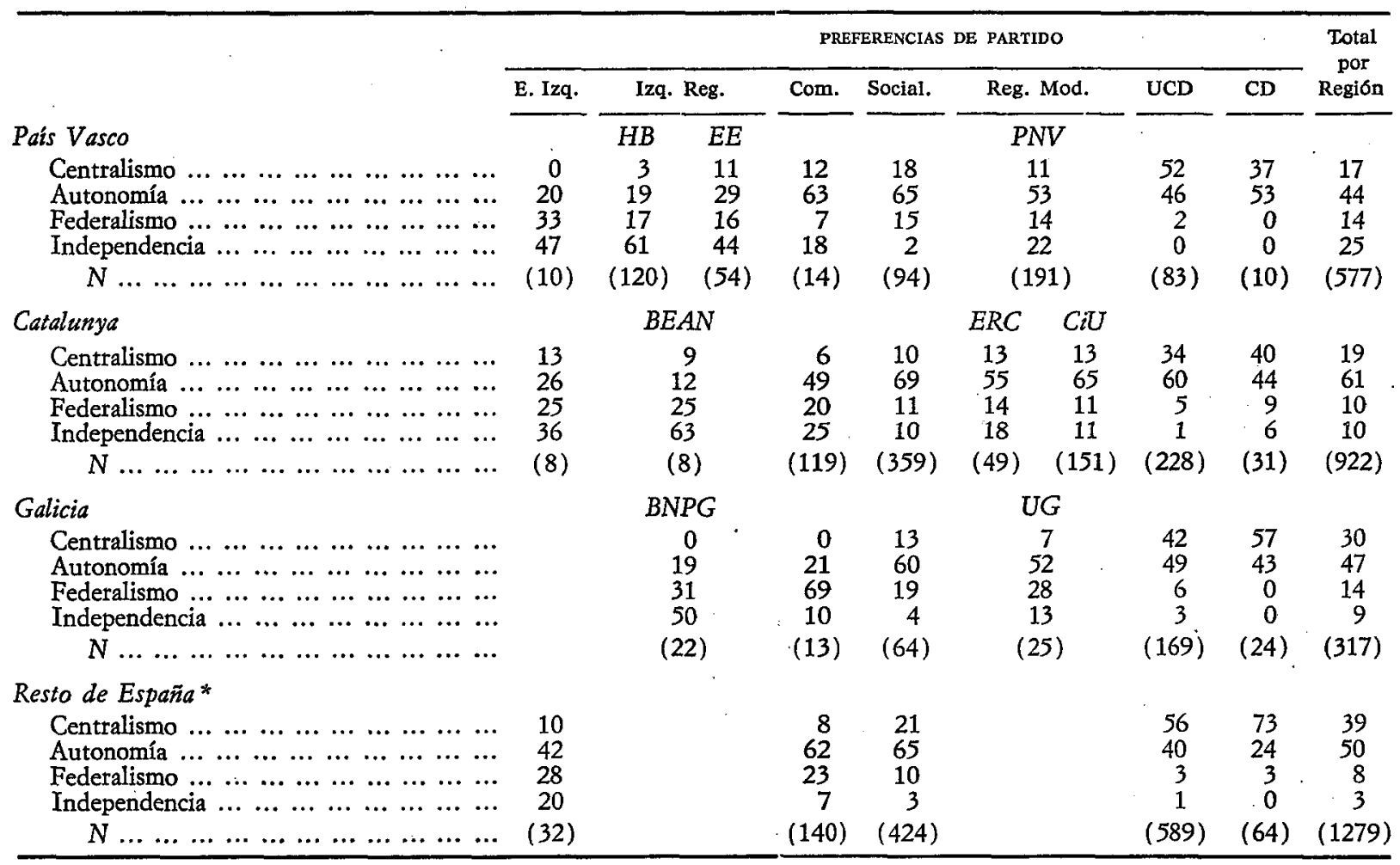

- Los datos de Navarra y Valencia no están incluidos. Serán objeto de un detenido examen en próximos estudios. 
Dentro de cada una de estas tres regiones, las diferencias entre los diferentes grupos de simpatizantes por lo que concierne al grado óptimo de autogobierno son generalmente congruentes con las divisiones entre las élites. Con algunas excepciones, los simpatizantes de los partidos regionales aparecen más inclinados que los simpatizantes de los partidos estatales a favor del federalismo o de la independencia. Entre los simpatizantes de los partidos regionales una mayoría de los afiliados a Herri Batasuna, Euskadiko Ezkerra, BEAN y BNPG son independentistas; entre los votantes del PNV sólo el 22 por 100 se muestra a favor de la independencia. Así, la ambigüedad de las élites del PNV con respecto a la cuestión nacional tiene su correspondencia a nivel de masas.

Una similitud adicional entre las actitudes de las élites y los votantes se encuentra en la preferencia dominante por la autonomía que muestran los simpatizantes del PSOE y el PCE en comparación con los que lo hacen por CD y UCD. Finalmente, la mayor simpatía que las élites de los partidos estatales expresan en Euskadi, Cataluña y Galicia por las demandas regionales, comparadas con las élites de estos partidos en cualquier otro lugar de España, tiene su correspondencia entre los simpatizantes de los partidos estatales en estas tres regiones.

Si bien una amplia mayoría de las élites y votantes de todos los partidos, incluso en la zona vasca, no están a favor de la independencia para las minorías regionales, el electorado expresa el deseo de que la independencia fuera garantizada si una mayoría de la población regional así lo desease. Como muestran las cifras del cuadro 8, una vez más los vascos encabezan esta posición con un 77 por 100 a favor de la misma. Pero incluso en Cataluña y Galicia, donde los sentimientos a favor de la independencia son compartidos por no más del 10 por 100 de la población, una mayoría está dispuesta en esa situación a aceptar la independencia. De los diferentes grupos de simpatizantes sólo entre los de UCD y CD (los vascos que votan a CD son una excepción) se encuentran importantes mayorías que no adoptan esta posición.

El electorado español muestra bastante menos desacuerdo en sus actitudes hacia aquellos que utilizan la violencia para conseguir sus objetivos nacionalistas que sobre la cuestión de la autonomía regional misma. El cuadro 9 refleja las puntuaciones medias alcanzadas por las poblaciones regionales y los simpatizantes de los partidos dentro de las regiones sobre un «termómetro de sentimientos» para medir la simpatía hacia ETA. (La media más baja muestra el mayor grado de antipatía hacia ETA.) Con tres excepciones notables - aquellos que pertenecen a Herri Batasuna, Euskadiko Ezkerra y los partidos de extrema izquierda en el País Vasco (cuyas puntuaciones medias, 6,5, 5,0 y 7,4, respectivamente, reflejan posiciones neutrales o positivas)-, existe una extendida hostilidad hacia ETÁ en todos los encuestados, con independencia de su afiliación partidista. No obstante ello, las variaciones en la intensidad de tal hostilidad resultan evidentes, como era de esperar, entre las diferentes regiones, entre los simpatizantes de los partidos regionales radicales y moderados y entre los simpatizantes de los partidos estatales y regionales.

Por lo que se refiere a las opiniones que conciernen a lo que el Gobierno debería hacer sobre el terrorismo (aceptar las demandas terroristas, negociar, 
CUAdRo 8

PORCENTAJES DE RESPUESTAS A LA PROPOSICION «INDEPENDENCIA REGIONAL SI LA POBLACION LO QUIERE» POR REGION Y PREFERENCIAS PARTIDISTAS

\begin{tabular}{|c|c|c|c|c|c|c|c|c|c|c|}
\hline \multirow[b]{3}{*}{ Pais Vasco } & \multicolumn{9}{|c|}{ PREFERENCIAS DE PARTIDO } & \multirow{3}{*}{$\begin{array}{c}\text { Total } \\
\text { por } \\
\text { Región }\end{array}$} \\
\hline & \multirow[t]{2}{*}{ E. Izq. } & \multicolumn{2}{|c|}{ Izq. Reg. } & \multirow[t]{2}{*}{ Com. } & \multirow{2}{*}{ Social. } & \multirow{2}{*}{\multicolumn{2}{|c|}{$\frac{\text { Reg. Mod. }}{P N V}$}} & \multirow[t]{2}{*}{ UCD } & \multirow[t]{2}{*}{ CD } & \\
\hline & & $H B$ & $E E$ & & & & & & & \\
\hline $\begin{array}{lllllllllllll} & \text { Sín } & \ldots & \ldots & \ldots & \ldots & \ldots & \ldots & \ldots & \ldots & \ldots & \ldots & \ldots\end{array}$ & 95 & 96 & 92 & 78 & 57 & & & 36 & 83 & 77 \\
\hline 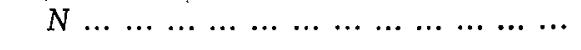 & $(10)$ & $(127)$ & $(54)$ & (13) & (79) & & & $(80)$ & (10) & (568) \\
\hline Catalunya & & $B E$ & & & & $E R C$ & $\mathrm{CiU}$ & & & \\
\hline 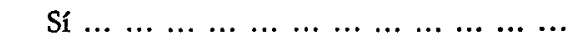 & 75 & 10 & 0 & 80 & 73 & 78 & 64 & 27 & 23 & 59 \\
\hline 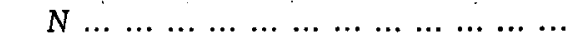 & (8) & ( & 7) & $(118)$ & (323) & (47) & (95) & (204) & $(25)$ & (847) \\
\hline Galicia & & $B N$ & $P G$ & & & & & & & \\
\hline $\begin{array}{llllllllllll} & \text { Sí } & \ldots & \ldots & \ldots & \ldots & \ldots & \ldots & \ldots & \ldots & \ldots & \ldots\end{array} \ldots$ & & & 2 & 82 & 69 & & & 43 & 10 & 56 \\
\hline 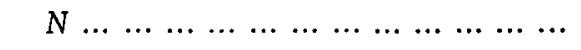 & & $(2$ & 4) & (13) & $(61)$ & & & (148) & (22) & (296) \\
\hline
\end{tabular}

Resto de España

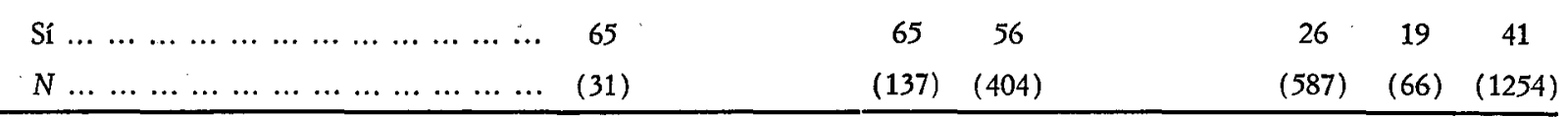


Cuadro 9

SIMPATIA MEDIA HACIA ETA SEGUN REGION Y PREFERENCIAS PARTIDISTAS SOBRE UN «TERMOMETRO DE SENTIMIENTOS» (EN PORCENTAJES)

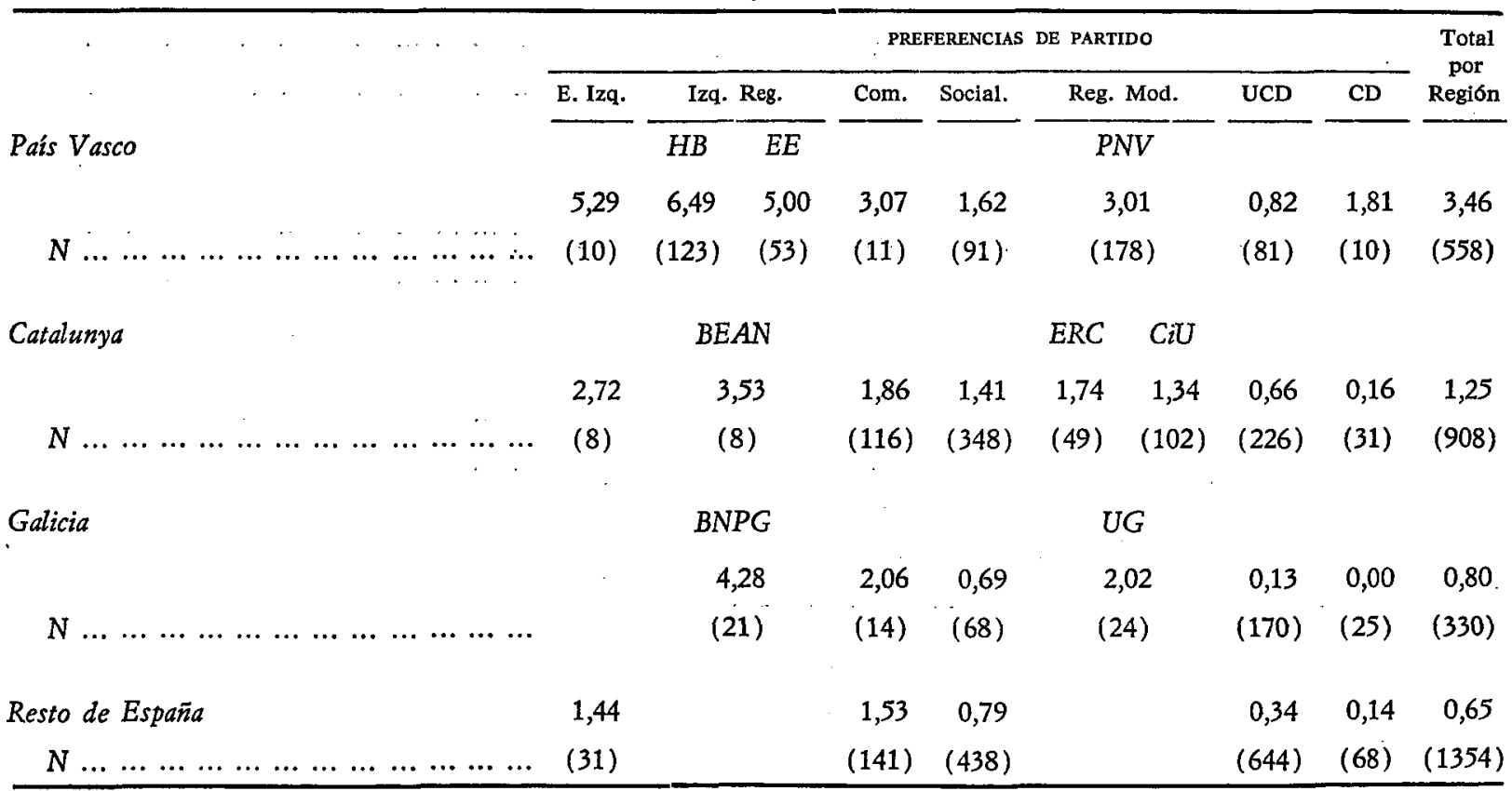


mantener la autoridad y el orden respetando los derechos civiles, declarar la guerra al terrorismo utilizando todos los medios a su alcance o establecer un régimen militar), tanto las diferencias regionales como entre partidos vuelven de nuevo a evidenciarse claramente a nivel de masas. Tal y como indica el cuadro 10, a diferencia de en otras partes de España incluyendo Cataluña y Galicia, una clara mayoría de vascos (57 por 100) se declaran a favor de aceptar las demandas terroristas o de la negociación. Más aún: los simpatizantes de todos los partidos en las provincias vascas se muestran más inclinados que sus homónimos en cualquier otro lugar a adoptar esta posición. Sustanciales y perceptibles diferencias sobre cuál debiera ser la actitud del Gobierno se encuentran en todas las regiones de España y aparecen estrechamente relacionadas con las preferencias partidistas. En ninguna zona más del 25 por 100 de los simpatizantes de UCD creen que el Gobierno debiera aceptar las reivindicaciones terroristas o negociar. En ningún lugar más del 30 por 100 de los simpatizantes de los partidos regionales radicales se manifiesta a favor de las alter-. nativas gubernamentales como respuesta al terrorismo.

Los líderes de los partidos en las tres regiones expresaron frecuentemente preferencias bastante diferentes con respecto a la política lingüística. Además de ello, como vimos anteriormente, adoptaron complejas posiciones con respecto al status relativo de la lengua regional versus el castellano y la primacía de una u otra en los distintos niveles educativos. A nivel de masas, sin embargo; considerables mayorías en toda España y entre la mayor parte de los grupos simpatizantes se mostraban a favor del estudio obligatorio a la vez de la lengua regional y del castellano (véase cuadro 11). Contrariamente a lo que ocurría a nivel de élite, donde se encontraban discrepancias con respecto a la política lingüística entre los líderes de los partidos regionales y estatales, aparecen escasas divergencias entre los simpatizantes de Herri Batasuna, Euskadiko Ezkerra, Convergència, el PNV y Unidade Galega, de un lado, y los simpatizantes del PCE y del PSOE, de otro. Sólo los puntos más extremos del espectro de partidos ( $\mathrm{CD}$ y los partidos regionales izquierdistas en Cataluña y Galicia) tienden a desviarse de este amplio consenso.

Los modelos: de cómo debe orientarse el problema regional resultan bastante diversos a. nivel de masas. Por lo que respecta a ciertos aspectos del nacionalismo periférico, tales como la política lingüística y el terrorismo, aparecen amplias coincidencias tanto entre las regiones como entre los grupos de partidarios. Otros aspectos como el tema crucial del grado de autonomía generan una considerable división regional, centro-periferia y partidista. En la mayoría de los temas, los vascos tienden a ser más nacionalistas que otros grupos y al mismo tiempo a estar más polarizados en torno a los partidos. Esto es consistente con la pauta de comportamiento a nivel de élite. De otro lado, las posiciones a nivel de masas de catalanes y gallegos relativas a la cuestión regional ofrecen algunas diferencias que podrían haber sido anticipadas a partir de las posiciones y declaraciones de los líderes políticos en estas dos regiones. Sobre la base de lo último se llega a la conclusión de que los gallegos son los menos politizados de los tres grupos regionales. Aunque las posiciones adoptadas por gallegos y catalanes son bastante similares, el apoyo a los partidos regionales en Galicia es considerablemente menor que en Cataluña. Así, 
CuAdro 10

PORCENTAJE DE RESPUESTAS FAVORABLES A ACEPTAR LAS DEMANDAS O NEGOCIAR CON LOS TERRORISTAS

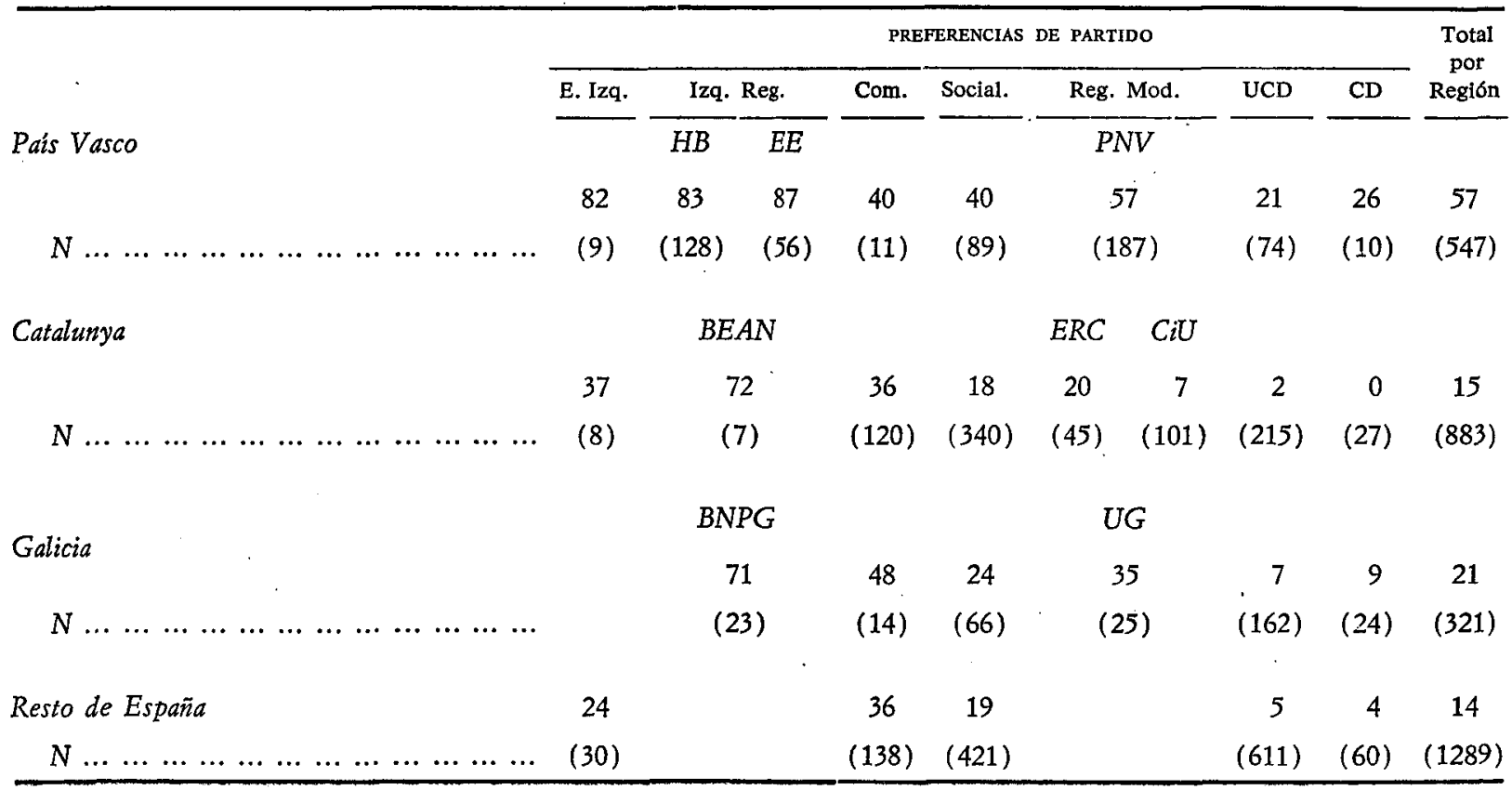


PREFERENCIAS EN PORCENTAJES POR LO QUE RESPECTA A LA OBLIGATORIEDAD DEL APRENDIZAJE DE LA LENGUA REGIONAL VERSUS EL CASTELLANO, POR REGION Y PREFERENCIAS PARTIDISTAS

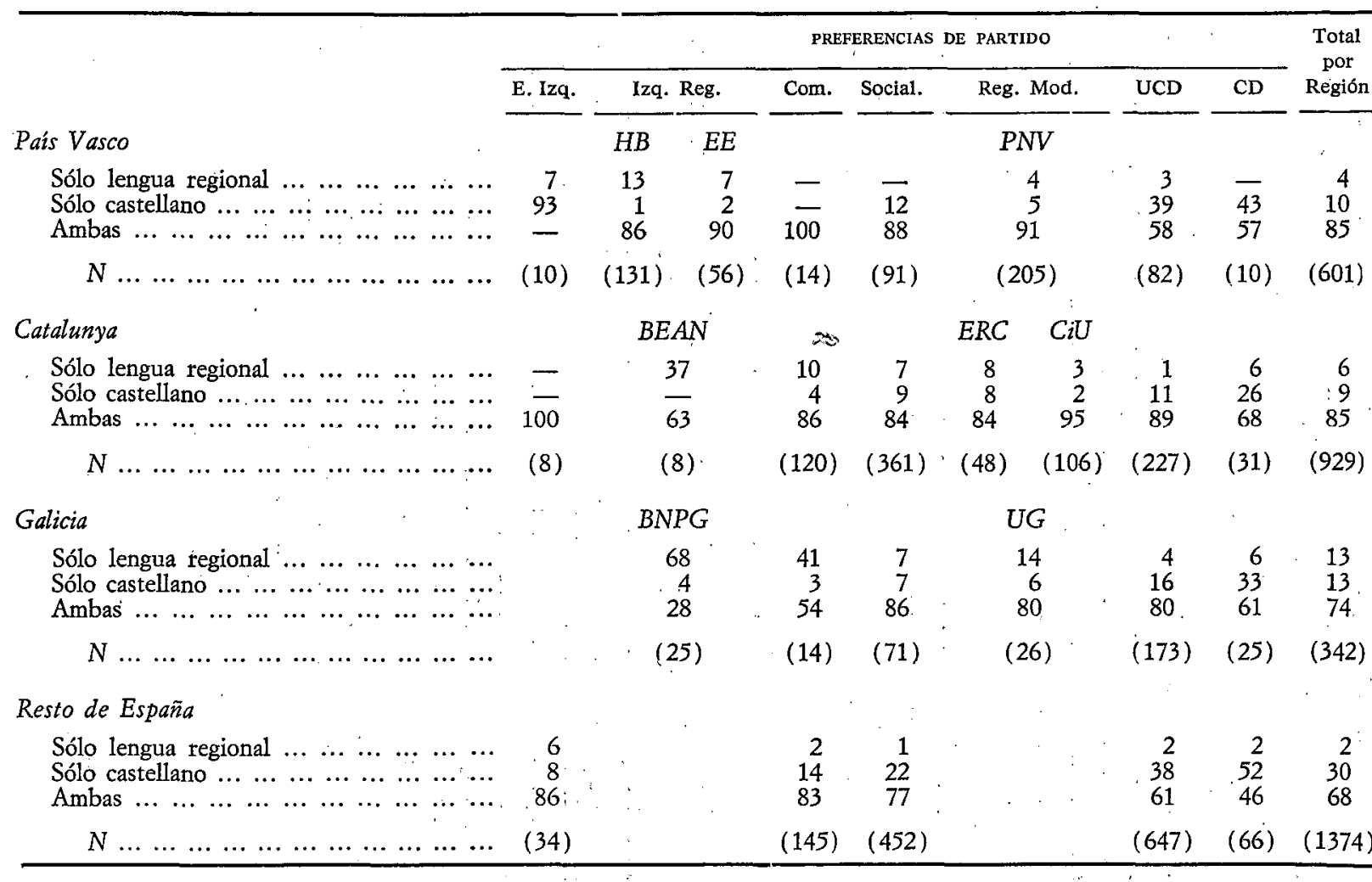

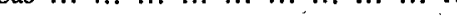


aparece en esta región una disfunción entre el nivel de sentimientos nacionalistas dentro de la población y el grado en que éstos se transforman en apoyo hacia los partidos regionales. Una explicación plausible de este fenómeno fue dada por un líder de AP, como se señaló anteriormente, quien pensaba que ello tenía que ver con la ausencia de partidos regionales en Galicia cuyas ideologías se correspondieran con las inclinaciones políticas conservadoras de amplios sectores de la población.

Por último, resulta claro que las tensiones regionales, si se las compara con las tensiones basadas en la religión y en la clase, son la fuente más importante de conflicto político en España. Hemos visto que la religión a nivel de masas está estrechamente relacionada con las lealtades partidistas; además de ello, los líderes de los partidos hicieron deliberados esfuerzos en la campaña de 1979 para no explotar estas divisiones con fines electorales. Por lo que se refiere a las escisiones de clase, el llamamiento interclasista de las élites de los partidos quedó reflejado en el variado componente de clase de las bases del apoyo partidista. Por lo que hace a la cuestión regional, existían divisiones más marcadas entre las élites y los votantes. Además en el País Vasco, y en menor grado en Cataluña, la polarización en torno a este problema no parece haber acabado incluso después de la concesión de la autonomía.

\section{LA INTERSECCION DE LAS DIVISIONES}

Hasta aquí hemos considerado las tres escisiones separadamente. Podríamos preguntarnos hasta qué punto cada una de ellas está ligada a la otra. La literatura sugiere que el impacto de las divisiones en el conflicto político puede ser magnificado o reducido, dependiendo de si y hasta qué punto las más significativas de éstas aparecen interconectadas. Se ha argumentado que su superposición tiene un efecto de refuerzo, mientras que su entrecruzamiento tiende a mitigar el conflicto.

Aunque la forma de los conflictos afecte posiblemente al comportamiento de la élite, vamos a considerarlo aquí sólo en relación al nivel de masas.

Para aproximarnos a este problema hemos optado por utilizar indicadores bastante simples de las posiciones de los votantes con respecto a estas tres divisiones. Para las dimensiones religiosas y de clases hemos utilizado un «termómetro de sentimientos», midiendo la simpatía hacia la Iglesia y las grandes empresas, respectivamente. Sin duda tales indicadores son una medida subjetiva más que objetiva de las dos divisiones. Para el problema regional hemos utilizado la preferencia de los votantes según una escala de alternativas que van del centralismo a la independencia.

En los diagramas 1, 2 y 3 hemos colocado las posiciones medias de cada grupo partidista sobre nuestras medidas, tomando dos al tiempo. Inmediatamente aparece que los sentimientos hacia la Iglesia y las grandes empresas tienden de forma muy pronunciada a ir unidos. Igualmente claro resulta que los diferentes grupos de simpatizantes se encuentran agrupados en un significativo orden izquierda-derecha. Este mismo modelo es utilizado con respecto a la relación entre religión y región y entre clase y región. Realmente, las po- 


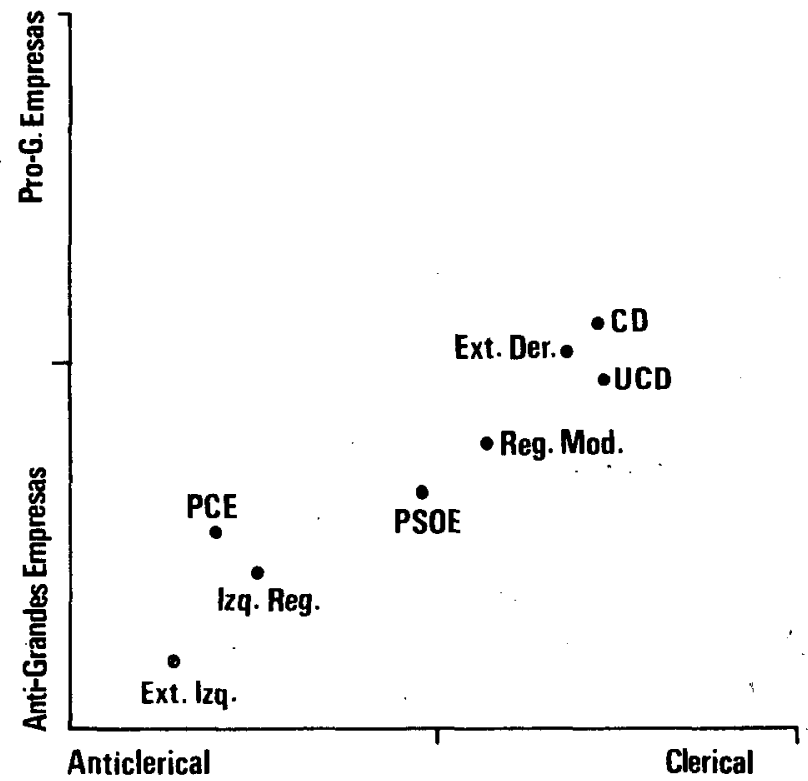

Diagrama 1.-Simpatía media hacia la Iglesia y las grandes empresas por grupos de simpatizantes.

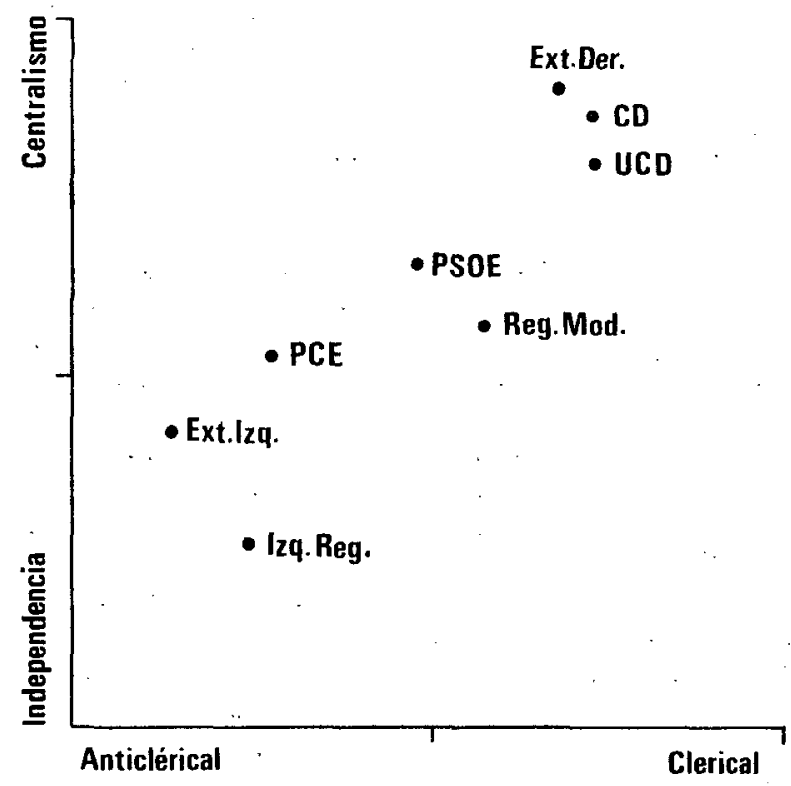

Diagrama 2.- Simpatía media por la Iglesia y posición sobre la autonomía regional por grupos de simpatizantes. 


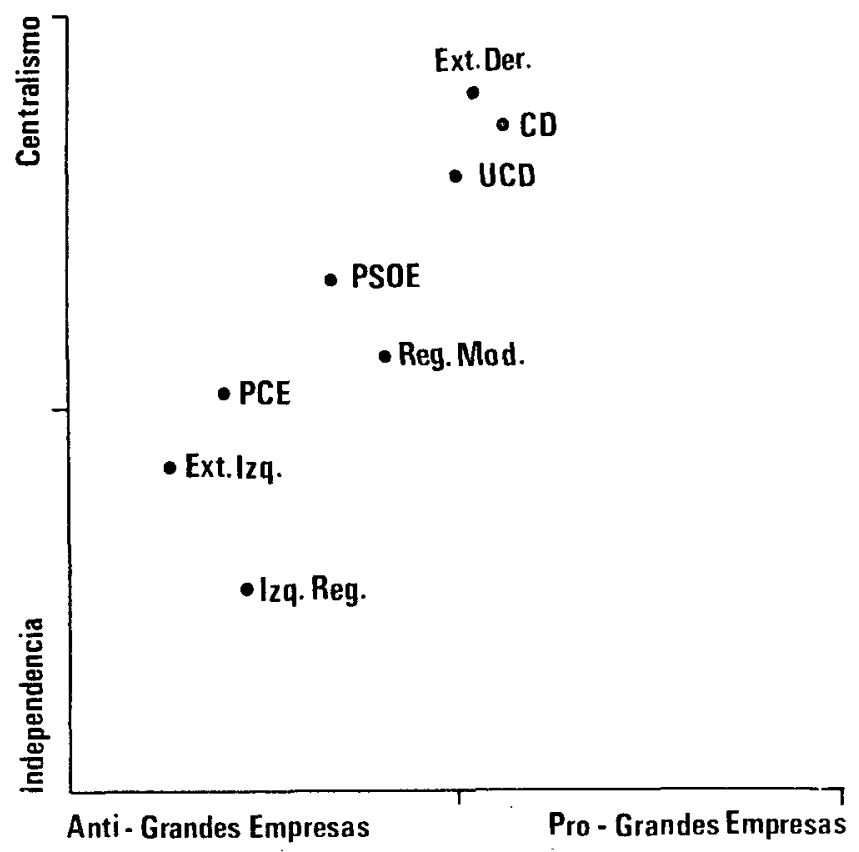

Diagrama 3.- Simpatía media hacia las grandes empresas y posición sobre la autonomía regional por grupos de simpatizantes.

siciones de los diferentes grupos en relación a una u otra varían en cierta medida, dependiendo de las específicas escisiones consideradas. Las posiciones moderadas o radicales de los simpatizantes de los partidos regionales se hacen más notorias cuando la dimensión regional es introducida. No obstante, una estructuración de conjunto izquierda-derecha aparece bastante nítidamente.

Dada la importancia de la división regional, la cual ha dado lugar a un sistema de partidos regional, es importante determinar si los modelos encontrados a nivel estatal se pueden hallar también a nivel de región. Como el cuadro 12 muestra, el modelo de interrelaciones es considerablemente similar en toda España tanto con respecto a la magnitud como a la dirección. En el País Vasco, sin embargo, algunas de las relaciones parecen ser más débiles que en otros lugares. En particular, las actitudes hacia la cuestión regional aparecen relacionadas más débilmente con nuestras indicaciones de clase y religión. En la zona vasca un fuerte apoyo al regionalismo se puede encontrar tanto entre los votantes más radicales como entre los más moderados.

Dos conclusiones surgen de estos resultados. La primera es que las tres tensiones parecen superponerse en bastante medida, tal y como la magnitud de las correlaciones indica. Por supuesto, las valoraciones variarán dependiendo de la particular estadística utilizada. Dado que los coeficientes del producto- 


\section{CUADRO 12}

INTERCORRELACIONES («Pearson's $r »$ ) ENTRE LOS INDICADORES DE «CLASE», «RELIGION», «REGION» Y AUTOSITUACION IZQUIERDA-DERECHA

\begin{tabular}{|c|c|c|c|c|}
\hline & Clase & Religión & Región & \\
\hline \multicolumn{5}{|l|}{ País Vasco } \\
\hline 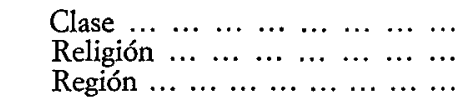 & E & $\underline{0,39}$ & $\begin{array}{l}-0,17 \\
-0,29 \\
-\end{array}$ & $\begin{array}{r}0,29 \\
0,49 \\
-0,42\end{array}$ \\
\hline
\end{tabular}

Catalunya

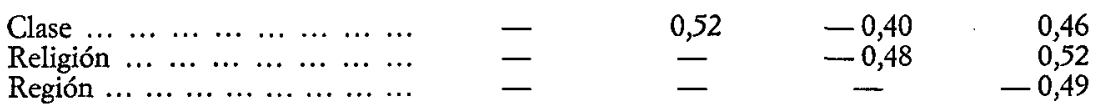

\section{Galicia}

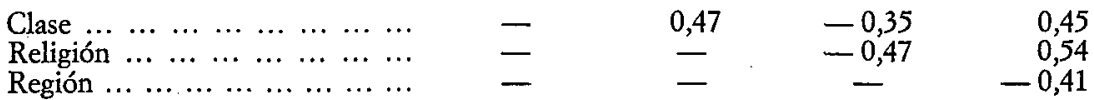

\section{Resto de España}

Clase

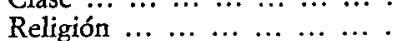

Región $\ldots \ldots \ldots \ldots \ldots \ldots \ldots \ldots$

\begin{tabular}{lllr}
- & 0,45 & $-0,29$ & 0,41 \\
- & - & $-0,36$ & 0,52 \\
- & - & $-0,42$ \\
\hline
\end{tabular}

momento aplicados a los datos de la encuesta tienden a atenuar la fuerza de las relaciones, el grado de superposición en España es notable. Datos comparativos de otras naciones europeas occidentales con respecto a la conexión entre sentimientos hacia la Iglesia y las grandes empresas indican que la relación en España es tan alta o más que en Alemania Occidental $(0,44)$ y Holanda $(0,43)$ y considerablemente más pronunciada que en Italia $(0,37)$, Finlandia $(0,36)$, Austria $(0,31)$ y Suiza $(0,23)^{44}$.

La segunda conclusión que se puede trazar se refiere a la fuerte relación entre la autosituación del encuestado sobre una escala izquierda-derecha y sus inclinaciones en relación a las tres divisiones. Cualesquiera otras connotaciones más explícitas que las orientaciones izquierda-derecha pudieran tener, es claro que también reflejarían las posiciones de los votantes respecto a las tres escisiones sociales más importantes en España.

4 Estos han sido calculados por los autores sobre la base de los datos ofrecidos en el Eight Nation Study. 


\section{IZQUIERDA-DERECHA Y ESTRUCTURA DE LA COMPETICION INTERPARTIDOS}

En principio los partidos no están limitados por los sectores del electorado que desean atraer. De la misma forma, los votantes tienen ante ellos una variedad de posibilidades, al menos en sistemas multipartidistas. En realidad en ningún país la competición entre dos o entre varios partidos se encuentra totalmente estructurada. Tanto los líderes de los partidos como las masas están condicionados por la autoimagen de los partidos, además de por las percepciones populares de éstos. Ello ayuda a estructurar las estrategias de los partidos y a limitar las alternativas de los votantes, afectando así a la competición interpartidos. Nuestros datos sugieren que esas limitaciones provienen en buena medida de las ubicaciones izquierda-derecha tanto de los partidos como de los votantes, además de las percepciones mutuas de donde cada uno de ellos se encuentra situado. Intentaremos ilustrar este aspecto general y responder a las dos cuestiones siguientes: ¿Por qué grupos de votantes compiten los partidos? ¿Qué opciones son percibidas como aceptables por los diferentes sectores del electorado?

Con frecuencia los miembros de los partidos que entrevistamos hicieron referencias a sus objetivos políticos definidos en términos izquierda-derecha. Se puede suponer con certeza que eran conscientes de la distribución del electorado español dentro del espectro político; de hecho muchos de ellos aludieron a estudios de opinión pública que venían a demostrar que el grueso de los votantes era bastante moderado. Es decir, éstos se encontraban situados bastante más en posiciones de centro e intermedias que en los extremos. Ello explica la prevalencia de una dirección centrípeta en la competición interpartidos.

Esto, junto a la clasificación izquierda-derecha de los partidos, significaba que cada uno de ellos debería estar fundamentalmente preocupado con sus dos vecinos más cercanos y prestar la mayor atención a aquél de los dos que se encontrara más cerca del centro. Cuando los partidos se dirigían al más «radical» de sus vecinos era básicamente para poner de manifiesto el despilfarro que suponía votar por un partido minoritario (voto útil). Aunque su objetivo era atraer los votos de los grupos más próximos, en algunas ocasiones dirigieron sus ataques además a otros partidos. No obstante, cuando los comunistas acometían contra Suárez, el Gobierno y las fuerzas de la derecha sus objetivos eran más atacar al ala izquierda de los socialistas, que se mostraba descontenta con lo que entendían era una posición excesivamente moderada del PSOE, que intentar convencer a los votantes de centro-derecha. Similarmente, cuando los líderes de CD hablaban de un «crecimiento de la amenaza roja» sus objetivos eran los votantes de UCD, quienes podrían encontrarse preocupados por las posiciones conciliadoras del partido con la izquierda.

Estas estrategias quedaron claramente evidenciadas en nuestras entrevistas con las élites de los partidos. Los miembros de UCD resultaban bastante consistentes en sus descripciones de los grupos ideológicos que deseaban atraer. Tanto en las entrevistas pre como poselectorales, declararon que sus objetivos eran aquellos sectores del electorado situados en el centro del espectro político, fronterizos por un lado con la «derecha democrática» y por otro con la social- 
democracia no marxista. El terreno ideológico delimitado por UCD resultaba así densamente poblado. Estudios de los que dispusieron las élites antes de las elecciones indicaban que en 1976 menos del 10 por 100 del electorado español se autodefinía como «marxista» y sólo un 17 por 100 se autoemplazaba en la «derecha». No obstante, de acuerdo con nuestros entrevistados, el esfuerzo principal de la campaña desarrollada por UCD a nivel nacional se encontraba primariamente dirigido hacia un sector específico de esta amplia y potencial audiencia, los moderados del centro-izquierda. A este grupo se le concedió una gran importancia dada la fuerza que el PSOE parecía demostrar, y dado el convencimiento, expresado en una entrevista antes de las elecciones por un miembro de UCD en Madrid, de que «un tercio del electorado de UCD y del PSOE es de hecho intercambiable, constituye un voto fluido y fluctuante». Las bases de la estrategia de UCD eran explicadas por un alto dirigente del partido en la forma siguiente:

En España está emergiendo una hegemonía de dos partidos entre UCD y el PSOE. Uno u otro de estos partidos ganará las próximas elecciones. Para conseguirlo tendrá que atraerse el 10 por 100 de los votos situados en el centro del espectro político. Este sector de los votos puede ir tanto a UCD como al PSOE. Para poder ganar UCD debe conseguir esos votos y posiblemente atraer a votantes del PSOE: Como mínimo debemos impedir que el PSOE nos robe votos. Para ello debe evitarse ofrecer una imagen conservadora o de partido de derechas. Tenemos que conseguir el apoyo de votantes progresistas. Otro entrevistado de UCD indicaba que esta lógica prevaleció en la conducta de la campaña de 1979.

Motivados por la misma creencia, el PSOE adoptó una estrategia similar. Como José Maravall (ahora miembro de la Comisión Ejecutiva Federal del PSOE) escribió:

La competición por el voto de centro-derecha es la consecuencia lógica del peso decisivo de este sector del electorado, 43 por 100 del total, del cual sólo un 8 por 100 ha votado al PSOE en 1977. Una victoria electoral de la izquierda requiere necesariamente el desplazamiento de este sector hacia el Partido Socialista... El PSOE esperaba ganar terreno aquí, toda vez que este electorado moderado frecuentemente estaba representado por pequeños campesinos y los niveles bajos de trabajadores no manuales, cuyo voto era mayoritariamente de tipo deferente ${ }^{45}$ (deferential kind), y podían ser atraídos a corto plazo por un Partido Socialista que contara con una fuerte presencia local y desarrollara una campaña adecuada ${ }^{46}$.

${ }_{45}$ Traducimos por «tipo deferente» el concepto inglés deferential kind. Dado que la equivalencia de los conceptos no es absoluta, indicamos entre paréntesis la expresión inglesa.

${ }^{4}$ José María Maravall, «Political Cleavages in Spain and the 1979 General Election», en Government and Opposition, Summer, 1979. 
Más sucintamente, un dirigente del PSOE de una de las provincias de Andalucía declaraba: "Nuestro objetivo es, indiscutiblemente, robar votos a UCD.» El PSOE intentó incrementar su fuerza atrayendo los votos de su flanco derecho. Esta decisión constituía parcialmente un paso hacia la socialdemocracia y un alejamiento del maximalismo; al final ello contribuyó a intensificar el conflicto interno del partido ${ }^{47}$. Los objetivos ideológicos de CD y del PCE eran en parte una respuesta a la lucha entre UCD y el PSOE por conquistar el centro del espectro político. Dado que los dos partidos mayores se dirigieron hacia el centro, los dos partidos menores que les seguían esperaban llenar lo que percibían como «espacio político» vacante a cada flanco de las dos organizaciones más centristas.

El PCE esperaba que, en la medida en que el PSOE se inclinara hacia el centro, aquellos socialistas que desaprobaban la socialdemocracia desertarían hacia el Partido Comunista. En la víspera del comienzo de la campaña, el líder del partido en Madrid, Simón Sánchez Montero, anunciaba públicamente que el PCE daría prioridad a la atracción de los simpatizantes del PSOE insatisfechos, y durante la campaña (e.g. intervención televisada de Santiago Carrillo el 26 de febrero) se hicieron llamamientos explícitos hacia aquellos socialistas instándoles a cambiar de lado.

De manera similar, CD esperaba conquistar a los votantes de centro-derecha que creyeran encontrarse abandonados por las desviaciones hacia la izquierda de UCD. Así, un partido usualmente percibido como partido de derechas incluso por muchos de sus miembros y líderes provinciales, se inclinaba hacia el centro para atraer antiguos votantes de UCD, redefiniéndose a sí mismo en el proceso como un partido de centro-derecha.

Existieron dos vías principales por las cuales los cuatro partidos más importantes intentaron ganarse el apoyo de los grupos a los que habían decidido dirigirse. El primero de ellos era empañar las características más significativas y radicales de sus ideologías o imágenes y remarcar aquellos aspectos que pudieran atraer a los votantes moderados. De esta forma, el PSOE minimizó durante la campaña referencias al marxismo, socialismo y a la ideología maximalista e intentó proyectar una imagen de partido socialdemócrata y reformista. UCD puso el acento en las reformas que hasta entonces había llevado a cabo: reforma fiscal, desmantelamiento pacífico del régimen franquista y aprobación de una Constitución democrática consensualmente elaborada. Asimismo, intentó distraer la atención sobre los antecedentes políticos franquistas o sobre los principios políticos conservadores de muchos de sus candidatos. El PCE proyectó una imagen de moderación, estabilidad y responsabilidad y suavizó el tono de las referencias al comunismo, marxismo y a los objetivos del partido a largo plazo de acabar con el capitalismo. Por lo que a $C D$ se refiere, de

${ }^{47}$ Culminó eventualmente, con la división temporal de los líderes del partido Felipe González y Alfonso Guerra. Las moderadas posiciones electorales adoptadas no contaban con una sanción ideológica formal y era claro que fueron decididas sin un consenso de los miembros del partido. Para muchos militantes del PSOE el término «socialdemócrata» es un insulto y la idea de que el PSOE pudiera algún día transformarse en algo parecido al SPD alemán resulta detestable. En las elecciones de 1977, sin embargo, la estrategia moderada de búsqueda del centro de González y Guerra prevalecería. 
acuerdo con un observador, «el primer objetivo de la campaña consistía en borrar todo lo que fuera posible la imagen de Alianza Popular después del fracaso de ese grupo en las elecciones del 15 de junio de $1977^{48}$. Esto se intentó llevar a cabo por medio de cambios en sus líderes, de evitar cuidadosamente referencias a favor del régimen franquista (que había constituido un rasgo notable en la campaña de AP en 1977), de una redefinición del partido como partido de centro-derecha más que de derechas y del cambio del nombre y símbolos del mismo».

La segunda vía consistía en exagerar ciertos aspectos de las posiciones ideológicas y de las imágenes del principal rival de cada partido en un esfuerzo por ahuyentar a los votantes de sus competidores. Así, el PSOE intentó dar una imagen de UCD como la de un partido muy conservador, muchos de cuyos líderes eran los herederos del autoritarismo franquista (por ejemplo, Alfonso Guerra describía al primer ministro Adolfo Suárez como un político que había andado a gatas «por las cloacas del franquismo») ${ }^{49}$. UCD respondió negando que el PSOE fuera un partido socialdemócrata y declarando a la vez que era marxista, revolucionario y peligroso. Un diputado y estratega electoral de UCD comentaba: «Sacamos un gran partido al término 'marxista' y de las declaraciones del 27 Congreso del PSOE. Incluso leíamos literalmente su definición de 'partido de clase, marxista, revolucionario y autogestionario'. Hemos citado literalmente lo que dicen en sus mítines... Realmente les hemos golpeado en este sentido.» En su intento de atraer al ala izquierda de los socialistas, el PCE exageró las desviaciones centristas de su rival socialista. Santiago Carrillo, por ejemplo, dijo en su último espacio en televisión durante la campaña: «Han podido ver que ellos (los socialistas) han olvidado el 27 Congreso y durante mucho tiempo han estado deslizándose hacia la socialdemocracia y han transformado el partido fundado por Pablo Iglesias en uno similar al de Willi Brandt. A ti, socialista, te digo que el único camino para llamar la atención de tus lideres y hacerles entender que hay otra política es votar comunista en las próximas elecciones» ${ }^{50}$. Por último, $C D$ intentó abrir una vía hacia los votantes del centro-derecha convenciéndoles de que UCD había traicionado su mandato electoral de 1977 , se había desviado hacia la izquierda y colaboraba con partidos marxistas. Una versión radicalizada de esta posición la daba el candidato de CD Luis Olarra: «El Gobierno de UCD no ha actuado como un partido de centro-izquierda, sino más bien de izquierda. Si UCD gana de nuevo España podría derivar hacia una situación tercermundista» ${ }^{51}$.

Las estrategias de los partidos $y$, por ello, su competición electoral estaba en parte basada en determinadas presunciones sobre las tendencias políticas del electorado español y sobre el posible comportamiento de los votantes. La primera era que los ciudadanos contemplaban el sistema de partidos en términos de izquierda-derecha, esto es, los partidos eran observados como ocupando diferentes posiciones en el espectro político y los votantes eran capaces de

* Columna de Camilo Valdecantos en El País, 28 de febreto de 1979, pág. 18.

49 El País, 9 de mayo de 1978, pág. 13.

so La cita está recogida de nuestra grabación de la emisión.

st El País, 17 de febrero de 1979, pág. 12. 


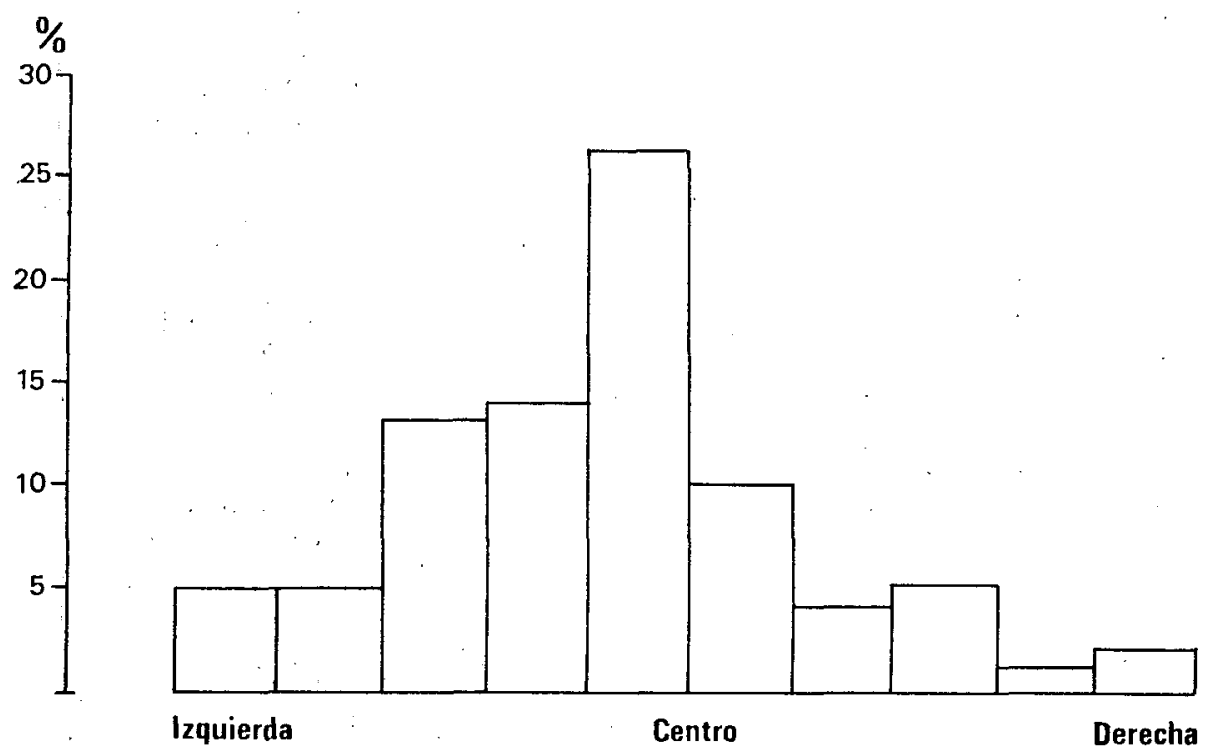

Diagrama 4.-Distribución del electorado español en el continuum izquierda-derecha.

relacionar estas posiciones con las suyas propias. La segunda, como hemos señalado, era la creencia de que la distribución del electorado en el continuum izquierda-derecha era básicamente unimodal con su cima más alta alrededor del centro. Y tercero, la presunción de que esta distribución se mantendría relativamente estable, es decir, que las posiciones de los votantes no fluctuarían, al menos drásticamente, a corto plazo. Volvemos a los datos de nuestra encuesta para considerar hasta qué punto tales presunciones estaban justificadas.

Nuestro estudio indica que los votantes son realmente capaces y están dispuestos a autosituarse en la escala izquierda-derecha: sólo un 13,9 por 100 respondió negativamente. Además, la distribución de estos autoemplazamientos está en línea con el unimodal modelo fuertemente asentado en el centro asumido por las élites políticas (véase diagrama 4). Los resultados de nuestros primeros estudios indican que esta distribución en su conjunto se ha mantenido fuertemente estable ${ }^{52}$. El emplazamiento de los partidos por los votantes demuestra además que el electorado era capaz de diferenciar muy bien las posiciones izquierda-derecha de las diferentes fuerzas políticas. En una escala de 1 (extrema izquierda) a 10 (extrema derecha), los cuatro partidos principales dieron las siguientes localizaciones medias: PCE, 2,5; PSOE, 3,9; $\mathrm{UCD}, 6,5$, y CD, 8,0 .

${ }^{52}$ Los datos de 1976 están recogidos en Vila Carro, Orizo y Gómez-Reino, Saciología actual del cambio en España. Para los datos de 1978 consultar McDonough, López Pina y Barnes, The Spanish Public in Political Transition. 
Para mayor seguridad, las percepciones de la situación de los partidos èra coloreada por las propias posiciones de los votantes. Aquellos que se identificaban con la derecha tenían en general una imagen más rädical del PCE que aquellos que votaban por la izquierda. De manera similar, las personas de izquierda consideraban más derechistas a UCD y CD que lo hacían los otros ${ }^{53}$. Aperecía, sin embargo, una unidad considerable en las posiciones medias izquierda-derecha de los diferentes grupos de simpatizantes, de un lado, y en las posiciones medias asignadas a sus respectivos partidos, de otro ${ }^{54}$.

Similarmente, y de igual importancia, resultó que las posiciones individuales izquierda-derecha se encontraban sistemáticamente relacionadas a sus sentimientos hacia los partidos principales y sus líderes. Los datos del cuadro 13 aportan una prueba para conocer el sentido en el que el sistema de partidos se encuentra espacialmente estructurado.

Cundro 13

\section{SENTIMIENTOS HACIA PARTIDOS Y POLITICOS SEGUN EL EMPLAZAMIENTO IZQUIERDA-DERECHA DE LOS ENCUESTADOS}

\begin{tabular}{|c|c|c|c|c|c|}
\hline \multirow{2}{*}{ AFECTO HACIA } & \multicolumn{5}{|c|}{ AUTOSITUACION IZQUIERDA-DERECHA * } \\
\hline & Izquierda & Centro Izq: & Centro & Centro Dha. & Derecha \\
\hline$\ldots \ldots \ldots \ldots$ & 5,7 & 5,1 & 2,8 & 1,7 & 0,8 \\
\hline Carrillo $\ldots \ldots \ldots \ldots$ & 5,6 & 5,1 & 2,9 & 1,9 & 0,9 \\
\hline $\begin{array}{llllll}\operatorname{PSOE} & \ldots & \ldots & \ldots & \ldots\end{array}$ & 5,4 & 6,5 & 5,0 & 4,1 & 2,6 \\
\hline González ... ... ....... & 5,5 & 6,5 & 5,2 & 4,4 & 3,1 \\
\hline $\mathrm{UCD} \quad \ldots \ldots \ldots c c c c$ & 1,6 & 3,5 & 6,3 & 6,7 & 6,5 \\
\hline $\begin{array}{llllll}\text { Suárez } & \ldots & \ldots & \ldots & \ldots\end{array}$ & 2,4 & 4,2 & 6,6 & 7,2 & 6,8 \\
\hline $\begin{array}{lllllll}C D & \ldots & \ldots & \ldots & \ldots & \ldots\end{array}$ & 0,6 & 1,5 & 3,6 & 5,3 & 6,4 \\
\hline $\begin{array}{llllll}\text { Fraga } & \ldots & \ldots & \ldots & \ldots\end{array}$ & 1,1 . & 1,9 & 3,6 & 5,4 & 5,8 \\
\hline
\end{tabular}

- Fueron utilizados los siguientes grupos de puntuaciones izquierda-derecha: «Izquierda» (1-2); «Centro-Izquierda» (3-4); «Centro» (5-6); «Centro Derecha» (7-8); «Derecha» (9-10).

Una muestra incluso más llamativa de que efectivamente la estructura izquierda-derecha de los partidos y los votantes afectó a la competición electoral se puede encontrar en las respuestas dadas a la siguiente pregunta: « $¿$ Hay partidos por los que usted nunca votaría?» Como el cuadro 14 muestra, el rechazo de los partidos políticos estaba muy estrechamente relacionado con las posiciones individuales izquierda-derecha. Sobre un 70 por 100 de las personas que se identificaban con la derecha o el centro-derecha señalaban al Partido Comunista como una «opción imposible». De manera similar, grandes proporciones de los que se identificaban con la izquierda descartaban votar por UCD y CD.

${ }^{53}$.Para detalles, véase Giacomo Sani, «Old Cleavages in a New Democracy: The Mass Bases of Spanish Parties», trabajo presentado en el Symposium Internacional sobre España y los Estados Unidos en la Universidad de Florida, Gainesville, Florida, 3-7 de diciembre de 1979.

${ }^{54}$ Las puntuaciones medias de emplazamiento de los partidos por sus respectivos votantes eran: PCE, 2,7 y 2,7 ; PSOE, 3,9 y 3,8; UCD, 5,9 y 6,1 , y CD, 7,1 y 7,8 . 
CuAdro 14

«PARTIDOS POR LOS QUE NUNCA VOTARIA» Y EMPLAZAMIENTO IZQUIERDA-DERECHA DE LOS ENCUESTADOS

\begin{tabular}{|c|c|c|c|c|c|}
\hline \multirow[t]{2}{*}{ ' } & \multicolumn{5}{|c|}{ AUTOSITUACION IZQUIERDA-DERECHA * } \\
\hline & Izquierda & Centro Izq. & Centro & Centro Dha. & Derecha \\
\hline PCE $\ldots \ldots \ldots \ldots \ldots$ & 16,6 & 14,7 & 43,6 & 71,9 & 74,1 \\
\hline $\begin{array}{llllll} & \text { PSOE } & \ldots & \ldots & \ldots & \ldots \\
\end{array}$ & 17,8 & 4,2 & 10,7 & 26,3 & 50,4 \\
\hline $\mathrm{UCD} \ldots \ldots \ldots \ldots$ & 70,2 & 32,9 & 5,9 & 3,2 & 10,3 \\
\hline $\mathrm{AP} \quad \ldots \quad \ldots c c c c c$ & 80,6 & 66,8 & 24,5 & 13,5 & 14,4 \\
\hline
\end{tabular}

* Véase Cuadro 13.

A la luz de estos datos parecen encontrarse justificadas las presunciones de la élite sobre el electorado. En la medida en que las opciones de cada votante se encontraba claramente limitada a dos partidos (PCE o PSOE, PSOE - UCD, UCD o CD), la decisión de los líderes de dirigirse hacia su vecino más fuerte estaba bien fundamentada. Poco se podía ganar con ataques indiferenciados a todo el espectro político. Como un estratega de alto nivel en UCD declaraba, «el PCE realmente no nos atacó, nos ignoró. Su táctica era clara... Sabían perfectamente bien que atacándonos no podrían recoger votos y no podrían robarnos nuestra clientela, porque estamos a mucha distancia de ellos. También nosotros escogimos no atacarles».

El modelo de mobilidad electoral entre 1977 y 1979 estaba asimismo de acuerdo con nuestras interpretaciones sobre la competición interpartidos. Cuando los votantes no confirmaban su primera opción tendían a votar por los partidos ideológicamente contiguos (véase cuadro 15). Así, muy pocos de los vontantes del PCE en 1977 que hicieron una elección diferente en 1979 optaron por partidos de centro-derecha. Igualmente, el PCE recibió tan sólo unos pocos votos de anteriores votantes de UCD. El cuadro 15 refleja de igual manera un limitado deslizamiento de votantes entre UCD y el PSOE. Parece evidente que la intensidad con que se desarrolló la competición entre los dos partidos sirvió más para reforzar la lealtad de los vontantes que para erosionar la fuerza del adversario.

CuAdro 15

VOTO EN 1977 Y PREFERENCIA DE PARTIDO EN 1979 (EN PORCENTAJES)

\begin{tabular}{|c|c|c|c|c|c|c|c|c|}
\hline & $\begin{array}{c}\text { Extrema } \\
\text { Izq. }\end{array}$ & Com. & Social. & UCD & $\mathrm{CD}$ & $\begin{array}{l}\text { Extrema } \\
\text { Dha. }\end{array}$ & Otros & Total \\
\hline $\begin{array}{llllll}\text { Comunistas } & \ldots & \ldots & \ldots & \ldots\end{array}$ & 3,5 & 80,5 & 5,3 & 0,9 & - & - & 9,8 & 100 \\
\hline $\begin{array}{llllll}\text { Socialistas } & \ldots & \ldots & \ldots & \ldots\end{array}$ & 0,9 & 2,5 & 87,8 & 3,0 & 0,4 & - & 5,4 & 100 \\
\hline $\begin{array}{lllllll}\mathrm{UCD} & \ldots & \ldots & \ldots & \ldots & \ldots & \ldots\end{array}$ & 0,2 & 0,4 & 6,1 & 83,6 & 1,7 & 0,4 & 7,6 & 100 \\
\hline $\begin{array}{lllllllll} & \operatorname{AP} & \ldots & \ldots & \ldots & \ldots & \ldots & \ldots & \ldots\end{array}$ & - & - & 1,6 & 26,9 & 55,6 & 4,9 & 11,0 & 100 \\
\hline
\end{tabular}


Este modelo, en líneas generales, es también correcto a nivel regional. No obstante, debido a lo destacado de las tensiones regionales, particularmente en el País Vasco, grupos sustanciales de votantes se han deslizado entre 1977 y 1979 de un partido regional a otro, generalmente en beneficio de los más radicales de éstos.

\section{CuAdro 16 (A)}

VOTO EN 1977 Y PREFERENCIA DE PARTIDO EN 1979 EN CATALUNYA (EN PORCENTAJES)

\begin{tabular}{|c|c|c|c|c|c|c|c|c|c|c|c|c|}
\hline & & & $\begin{array}{l}\text { Extrema } \\
\text { Izq. }\end{array}$ & $\begin{array}{l}\text { Izq. } \\
\text { Reg. }\end{array}$ & PSUC & Social. & ER & $\mathrm{CiU}$ & UCD & $C D$ & Otros & Total \\
\hline PSUC ... & $\ldots$. & & 3 & 0 & 88 & 5 & 0 & 3 & 0 & 0 & - & 100 \\
\hline PSOE ... & $\therefore$. & $\ldots$ & 0 & 0 & 2 & 92 & 1 & 2 & 2 & 1 . & - & 100 \\
\hline ER ...... & $\ldots$ & $\ldots$ & 2 & 2 & 0 & 2 & 84 & 5 & 0 & 2 & 3 & 100 \\
\hline $\mathrm{PDC} \ldots$ & $\ldots$. & $\ldots$ & 0 & 0 & 3 & 4 & 4 & 79 & 0 & 10 & - & 100 \\
\hline $\mathrm{UCD} \ldots$ & $\ldots$... & $\ldots$ & 0 & 0 & 0 . & 6 & 0 & 9 & 84 & 1 & - & 100 \\
\hline AP $\ldots \ldots$ & $\ldots$ & $\ldots$ & 0 & 0 & 0 & 0 & 0 & 27 & 19 & 45 & 9 & 100 \\
\hline
\end{tabular}

CuAdro 16 (B)

VOTO EN 1977 Y PREFERENCIA DE PARTIDO EN 1979 EN EUZKADI (EN PORCENTAJES)

\begin{tabular}{|c|c|c|c|c|c|c|c|c|c|}
\hline & $\begin{array}{l}\text { Extrema } \\
\text { Izq. }\end{array}$ & HB & EE & PCE & PSOE & PNV & UCD & $\mathrm{CD}$ & Total \\
\hline $\mathrm{EE}$ & 8 & 39 & 45 & 0 & 2 & 6 & 0 & $\mathbf{0}$ & 100 \\
\hline PCE $\ldots \ldots \ldots \ldots$ & 8 & 21 & 0 & 71 & 0 & 0 & 0 & 0 & 100 \\
\hline $\begin{array}{lllll}\mathrm{PSOE} & \ldots & \ldots & \ldots\end{array}$ & 0 & 7 & 1 & 0 & 76 & 12 & 3 & 0 & 100 \\
\hline $\operatorname{PNV} \ldots \ldots \ldots \ldots$ & 0 & 11 & 3 & 0 & 1 & 83 & 2 & 0 & 100 \\
\hline $\mathrm{UCD} \ldots \ldots \ldots$ & 0 & 0 & 2 & 0 & 2 & 7 & 88 & 1 & 100 \\
\hline $\begin{array}{llllll}\mathrm{AP} & \ldots & \ldots & \ldots & \ldots\end{array}$ & 0 & 0 & 0 & 0 & 0 & 28 & 37 & 35 & 100 \\
\hline
\end{tabular}

Se podría plantear la objeción de que nuestro modelo unimodal supersimplifica las dinámicas de la competición interpartidos. Hemos visto, sin embargo, que las divisiones que se basan en la clase, religión y región se encuentran reflejadas en considerable grado en la identificación izquierda-derecha de los votantes. Además esto último se encuentra relacionado con otras inclinaciones en la vida política, tales como preferencias por la Monarquía versus República, valoración del Rey y de la policía, logros del régimen franquista y actitudes hacia los dos superpoderes. Ásí, aunque una visión unidimensional puede desde luego no hacer justicia a las complejidades de la multifacética vida política, es, sin embargo, un camino corto y eficaz para captar sus aspectos más importantes. 
Varios puntos surgen de nuestro análisis de las elecciones parlamentarias de 1979. Las tres divisiones históricamente más significativas han resurgido en la política española. De las tres, el problema regional parece ser el que produce mayores divisiones. Clase y religión, especialmente la última, aparecen a nivel de masas, relacionadas a las preferencias partidistas. Debido en parte a la actitud de la élite, las divisiones religiosas aparecen, sin embargo, como una fuente más potencial que actual de conflicto. Los alineamientos estrictamente políticos parecen ser más importantes que las divisiones sociales y económicas. Las dinámicas de la competición interpartidos parecen estar estructuradas en buena medida por las posiciones de partidos y votantes en el continuum izquierda-derecha. En todos estos aspectos aparece un significativo grado de correspondencia entre élite y masas y actitudes.

Si son correctas las presunciones acerca de la importancia que tienen los primeros estadios de un régimen político para su futuro desarrollo, debiéramos esperar que estos rasgos del sistema de partidos español se mantengan. De mantenerse todo igual, la naturaleza básicamente moderada del electorado español y la orientación centrípeta de las estrategias de las élites son un buen augurio para la estabilidad de la democracia política. 